\title{
Role of ley pastures in tomorrow's cropping systems. A review
}

\author{
Guillaume Martin ${ }^{1}$. Jean-Louis Durand ${ }^{2}$ - Michel Duru ${ }^{1}$ • François Gastal ${ }^{3} \cdot$ Bernadette Julier $^{2} \cdot$ Isabelle Litrico $^{2}$. \\ Gaëtan Louarn $^{2}$ - Safia Médiène ${ }^{4}$ - Delphine Moreau ${ }^{5}$ - Muriel Valentin-Morison ${ }^{4}$ - Sandra Novak ${ }^{3}$. \\ Virginie Parnaudeau ${ }^{6}$. Foteini Paschalidou ${ }^{4}$. Françoise Vertès ${ }^{6}$. Anne-Sophie Voisin ${ }^{5}$. Pierre Cellier ${ }^{7}$. \\ Marie-Hélène Jeuffroy ${ }^{4}$
}

Accepted: 18 March 2020 / Published online: 12 May 2020

(C) The Author(s) 2020

\begin{abstract}
Diversification of cropping systems has been proposed as a major mechanism to move towards sustainable cropping systems. To date, a diversification option that has received little attention is introduction of ley pastures into cropping systems, but the use of ley pastures is challenged by most future-oriented scenarios aiming to feed the world sustainably. In these scenarios, ruminant livestock feed only on permanent pastures, while cropping systems focus completely on production of crop-based human food. Diversification of cropping systems with ley pastures is thus compromised by knowledge gaps and future-oriented policy options. Here, we review ecosystem services provided by introducing ley pastures into cropping systems to increase sustainability of agriculture, discuss types of ley pastures and their management liable to promote these services, and raise future challenges related to introducing ley pastures into cropping systems. We conclude that (1) ley pastures provide a large set of input (soil conservation, nutrient provision and recycling, soil water retention, biological control of pests) and output (water purification, climate regulation, habitat provision for biodiversity conservation, forage production) ecosystem services of primary importance to cropping systems and society, respectively, as long as their spatial and temporal insertion within cropping systems is wellmanaged; otherwise, disservices may be produced. (2) To benefit from ecosystem services provided by ley pastures in cropping systems while limiting their disservices, it appears necessary to define a safe operating space for ley pastures in cropping systems. Moving towards this space requires changing plant breeding programs towards multiservice ley pastures, producing knowledge about emerging ways of introducing ley pastures into cropping systems (e.g., living mulch, green manure) and better quantifying the bundles of ecosystem services provided by ley pastures in cropping systems.
\end{abstract}

Keywords Ley pastures $\cdot$ Sown grasslands $\cdot$ Cropping systems $\cdot$ Ecosystem services $\cdot$ Scenarios

Guillaume Martin

guillaume.martin@inrae.fr

1 Université de Toulouse, INPT, INP-PURPAN, INRAE, AGIR, 31320 Auzeville, France

2 INRAE, P3F, 86600 Lusignan, France

3 INRAE, Ferlus, 86600 Lusignan, France

4 INRAE, AgroParisTech, Université Paris-Saclay, Agronomie, 78850 Thiverval-Grignon, France

5 AgroSup Dijon, INRAE, Univ. Bourgogne, Univ. Bourgogne Franche Comté, Agroécologie, 21000 Dijon, France

6 INRAE, Agrocampus Ouest, SAS, 35000 Rennes, France

7 Environment and Agronomy Division, INRAE, 78850 Thiverval-Grignon, France

\section{Contents}

1. Introduction

2. Theoretical framework

2.1. Characterizing management options for introducing ley pastures into cropping systems

2.2. Characterizing bundles of services provided by ley pastures in cropping systems

3. Input services provided by ley pastures in cropping systems

3.1. Soil conservation

3.2. Nutrient provision and recycling

3.3. Soil water retention

3.4. Biological control of pests and weeds

4. Output services provided by ley pastures in cropping systems

4.1. Water purification 
4.2. Climate regulation

4.3. Habitat provision for conserving associated biodiversity

4.4. Forage production

5. Which diversity of ley pastures for tomorrow's cropping systems?

5.1. Pasture species composition

5.2. Choice of varieties for mixtures

6. Research agenda

6.1. Defining a safe operating space for ley pastures in cropping systems

6.2. Breeding varieties for multiservice pastures

6.3. Developing a knowledge base on ways to introduce ley pastures into cropping systems

6.4. Assessing bundles of ecosystem services provided by ley pastures in cropping systems

7. Conclusions

\section{Introduction}

Grain production has doubled in the past 50 years (Tilman et al. 2002) under the effect of more efficient machinery; improved varieties; and increased reliance on irrigation water, fertilizer, and pesticides. This trend has favored simplification and intensification of cropping systems (i.e., monocultures or crop sequences limited to 2 crops) (Aguilar et al. 2015; Barzman et al. 2015) and specialization of many agricultural regions. It has also led to the disappearance of ley pastures in regions where grain crops are dominant (Mignolet et al. 2012; Peyraud et al. 2014). Currently, these simplified cropping systems have stagnating yields (Brisson et al. 2010; Ray et al. 2012; Moore and Lobell 2015) and appear sensitive to global changes such as climate change (Brisson et al. 2010; Meng et al. 2016). Their strong reliance on mineral fertilizers and agrochemicals has negative impacts on the environment (e.g., pollution of air, water and soils; losses of soil quality and agroecosystem biodiversity; Sebilo et al. 2013) and human health (Kim et al. 2017). This reliance on synthetic inputs can even cause problems, such as emerging cases of resistance to agrochemicals, especially herbicides (e.g., ryegrass in wheat in Australia (Saini et al. 2015); windmill grass in soybean in Brazil (Brunharo et al. 2016)). Nonetheless, the trend of pesticide use is stable or increasing (e.g., in France; Ecophyto 2017), and agriculture continues to rely heavily on mineral fertilization (FAO 2019). To address these challenges, alternative agricultural models are increasingly needed.

Several directions have been proposed to move towards sustainable cropping systems, such as agroecology (Altieri 1989; Tomich et al. 2011), ecological intensification (Cassman 1999), ecoefficient agriculture, and sustainable intensification (Pretty and Bharucha 2014). Nearly all of these models rely on greater plant diversity in cropping systems.
Diversified cropping systems (Kremen et al. 2012) relying on agroecological principles should be more sustainable, as suggested by theoretical ecology studies (Isbell et al. 2011), cropping system experiments (Davis et al. 2012), and on-farm assessments (Carlisle 2014). A fine-tuned combination of functional complementarities of a variety of species provides a wide range of ecosystem services to sustain crop production through biological processes, with relatively low negative environmental impacts (Kremen and Miles 2012; Kremen et al. 2012). At the field level, several options exist to diversify cropping systems, such as mixing varieties, intercropping species, introducing cover crops, and increasing the diversity of crops in the crop sequences. These options have received frequent attention from the scientific community (e.g., Schipanski et al. 2014; Ponisio et al. 2015; Finney et al. 2017), but another option has received much less: introducing ley pastures into cropping systems (Fig. 1). Ley pastures are defined as temporary pastures that are integrated in crop sequences (Allen et al. 2011). They are composed of grasses, legumes, and/or other forbs and are grown from several months to 5 years at most (according to European Union (EU) regulations). Currently, they are located mainly in lowland agricultural regions dominated by ruminant livestock production to produce forage by haying, grazing, or both

Most future-oriented scenarios aiming to feed the increasing world population while improving the sustainability of agriculture converge towards a reduction of animal protein in human diets in developed countries (Westhoek et al. 2014; Schader et al. 2015; Röös et al. 2017; Muller et al. 2017). Along with this change in human diets, all but one scenario (Poux and Aubert 2018) suggest a shift in livestock's primary role in the food system from producing animal protein to extracting value from land unsuitable for food production (e.g., semi-natural pastures, wetlands), which cover two-third of worldwide agricultural area, through ruminant livestock grazing (Schader et al. 2015). This implies that livestock be located in areas less suitable for arable crop production and consume no feed supplements except food byproducts (e.g., meals, pulps). Accordingly, these scenarios assume that the land devoted to permanent pastures remains constant, as a "sustainable" way to feed ruminant livestock. However, if arable land is less or no longer used to produce ruminant livestock feed (including forage), ley pastures should appear less frequently in cropping systems devoted mainly to food production.

Diversification of agricultural systems and especially of cropping systems is thus confronted with future-oriented policy options designed to feed the world's human population more sustainably. We argue that potential benefits offered by introduction of ley pastures into cropping systems are currently underestimated. In this context, there is a need to clarify the bundles of ecosystem services provided by ley pastures introduced to improve sustainability of cropping systems, 


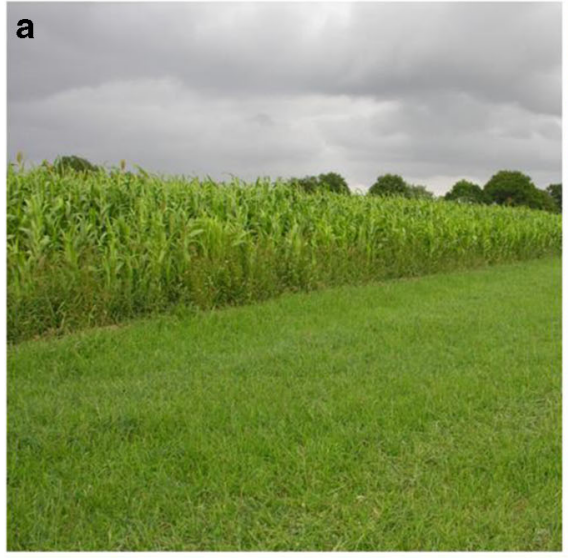

d

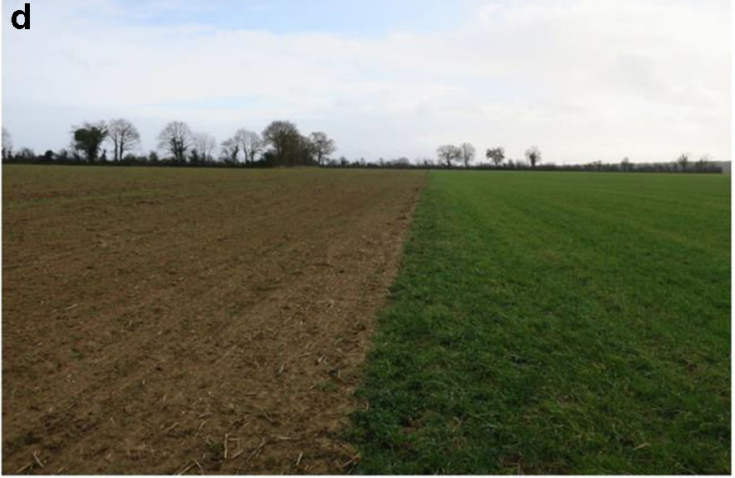

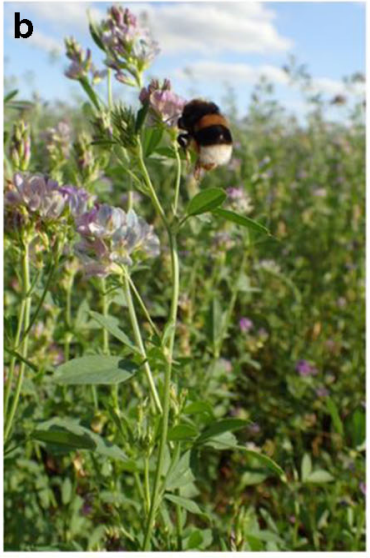

e

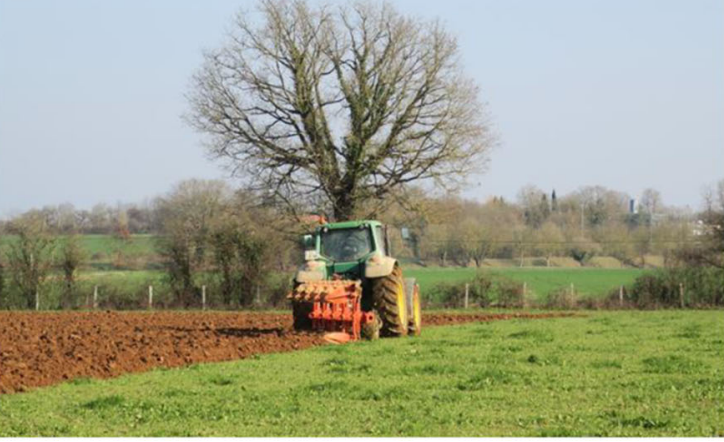

Fig. 1 Examples of cropping system situations including ley pastures. (Photo credits: Sandra Novak for a, b, d, and e, SOERE ACBB for c)

depending on their management. In this review, we (i) present a theoretical framework suited to analyze introduction of ley pastures into cropping systems, (ii) synthesize their potential benefits to improve sustainability of agriculture, (iii) discuss the types of ley pastures liable to promote these benefits, and (iv) raise future challenges related to introducing ley pastures into specialized cropping systems or mixed systems of crops and ruminant livestock.

\section{Theoretical framework}

\subsection{Characterizing management options for introducing ley pastures into cropping systems}

"Cropping system" refers to a crop sequence and management techniques consistently planned, adapted, and implemented by a farmer on a particular field over a period of years according to available resources (e.g., workforce, machinery) (Sebillotte 1990; Reckling et al. 2016). It describes systems of annual crops such as grains, forages (e.g., silage maize), and vegetables where ley pastures are a key component of the crop sequence (Amossé et al. 2013a, b; Weißhuhn et al. 2017), while in perennial woody-crop systems such as orchards and vineyards, pastures are usually restricted to areas next to the perennial crop of interest (Miglécz et al. 2015). Consequently, this review focuses on the former. Analysis of the introduction of ley pastures into cropping systems should consider the agricultural system in which the introduction takes place, the companion annual crop and/or the crop sequence, and the management techniques applied.

"Agricultural system" refers to the type of production system on the farm, i.e., arable, livestock, or mixed including crop, pastures, and livestock. "Crop sequence" refers to a sequence of plant species grown on the same piece of land (Dury et al. 2012). Knowledge of the position of ley pastures and the other crops (i.e., grain, forage or vegetable crops) in the crop sequence is required to understand effects of ley pastures on following crops. Beyond interactions among crop and pasture species, there are a variety of management techniques to consider when analyzing impacts of introducing ley pastures into cropping systems (Fig. 2). The first is the type of ley pasture (i.e., annual or perennial) and the species sown (i.e., grasses, legumes, or a mixture of both that may include other forbs). The second option is how the ley pasture is sown, usually on bare soil, but increasingly within a cash crop as "relay intercropping" (planting a second crop before the first crop is mature; McCormick et al. 2014). The third option is how the pasture is used. Traditionally, pastures were grazed and/or hayed. Other emerging uses of pastures include "living mulch" (partially killed before sowing using a power harrow or moderate herbicide spraying) to sow a crop in the ley pasture (Turlin 2017), 
Fig. 2 Overview of the theoretical framework developed to analyze introduction of ley pastures into cropping systems. Management options (on the left) for growing ley pastures within cropping systems affect bundles of services (on the right) provided by ley pastures in cropping systems

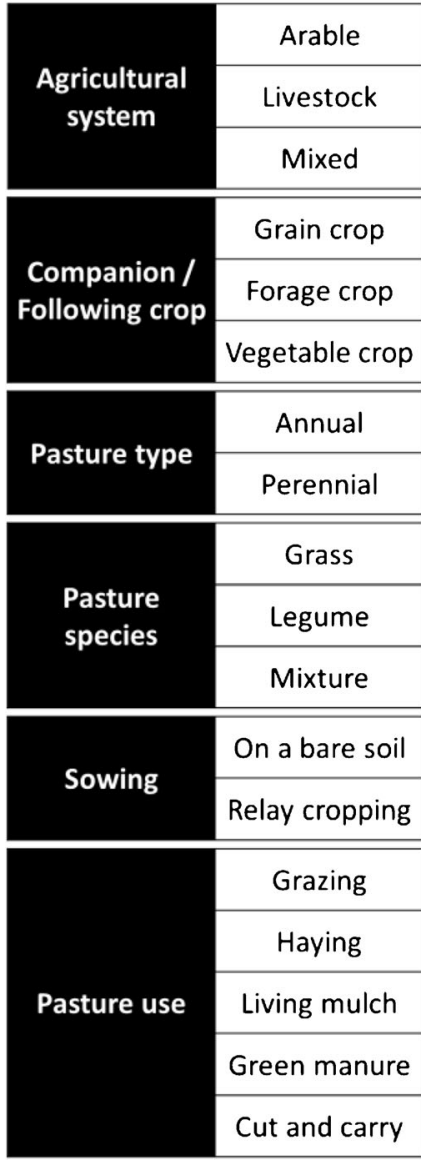

"green manure" (killed by crushing, e.g., with a power harrow, herbicide spraying or frost) for mulching or incorporating residues before sowing a crop (Fisk et al. 2001) and "cut and carry" by using legumes (fresh or dried) as sources of fertilizer on arable land (van der Burgt et al. 2013).

\subsection{Characterizing bundles of services provided by ley pastures in cropping systems}

Analyzing potential benefits offered by introducing ley pastures into cropping systems may rely on the concept of ecosystem service bundles (Raudsepp-Hearne et al. 2010). Bundles exist when provision of one service leads to changes in others or when the same factor drives changes in multiple services. Bundles thus describe interactions among services under the influence of the companion crop of ley pastures or the crop sequences in which ley pastures are integrated, as well as the techniques used to manage them. They can even reveal disservices, such as when introducing a ley pasture into a cropping system results in an outcome worse than not doing so (Finney et al. 2016).

Ley pastures may provide multiple ecosystem services (Fig. 2). When applying the ecosystem services framework to agriculture, it is common to distinguish services flowing to agriculture (input services) from those flowing from agriculture (output services), thus highlighting that agroecosystems both depend on and contribute to provision of ecosystem services (Zhang et al. 2007). Among input services, we considered the following, at various levels:

- Soil conservation (field level) by preserving its stability and controlling erosion. The former refers to the ability of soil aggregates to resist environmental stress (e.g., wet-dry cycles) without breaking, while the latter refers to preventing loss of soil particles due to wind, rain, or water flow.

- Nutrient provision and cycling (cropping system level). Nutrient provision refers to uptake and supply of nutrients to the following crop. Nutrient cycling refers to deposition, uptake, and decomposition of litter and animal manure in the soil, which allow recycling to occur.

- Soil water retention (field level), i.e., retaining soil water and providing it to the following crop.

- Biological control of pests and weeds (cropping system level), i.e., reducing or eliminating their populations by influencing their ecology.

Among output services, we considered the following, at various levels: 
- Water purification (watershed level), i.e., removing undesirable chemicals, contaminants, suspended solids, and gases from water.

- Climate regulation (global level), i.e., decreasing greenhouse gas emissions or increasing carbon (C) storage in the soil.

- Habitat provision for wildlife conservation (landscape level), i.e., providing high-quality functional and structural habitats for a wide range of animal and plant species.

- Production of forage for livestock (in both quantity and quality) or biomass to produce energy (Rösch et al. 2009).

Although knowledge is available about each service in ley pastures individually, services have rarely been quantified or considered together for ley pastures. In the following sections, we review these services to provide an integrated view of bundles of services provided by ley pastures in cropping systems.

\section{Input services provided by ley pastures in cropping systems}

\subsection{Soil conservation}

Soil structure directly impacts several aspects of soil functioning: water, solutes, fine particles, and gas transfers within the soil; development and activity of root systems; and biological activity (Bronick and Lal 2005). Stability of soil structure, often assessed by the degree of soil aggregation, strongly determines a soil's ability to resist and recover from disturbances (e.g., tillage, erosion). Soil aggregation and stability are generally positively related to soil organic matter (SOM) content (Bronick and Lal 2005). They are generally lower under annual crop sequences but higher under permanent pastures or during the ley pasture period of crop sequences (Haynes 1999; Diaz-Zorita et al. 2002; Franzluebbers and Stuedemann 2008; Puerta et al. 2018). Puerta et al. (2018) report increases in the proportion of large macroaggregates in the range $47-65 \%$ (depending on management: organic vs. conventional) after a ley period following a 4-year arable crop rotation. Thus, whatever the type of agricultural system, decreasing soil disturbance with practices like relay cropping and increasing $\mathrm{C}$ input by developing multiannual or short-duration (i.e., several months) ley pastures within sequences based on annual crops, regardless of their use, can greatly improve soil structure and, more generally, soil health (Fig. 3) and even more if associated with inputs of crop residues and animal manure (Franzluebbers and Gastal 2018).

Multiannual ley pastures also protect soil from water and wind erosion (Franzluebbers 2008; Franzluebbers et al. 2014). This is also the case when introducing short-duration ley pastures into arable cropping systems (e.g., as living mulch) during the fallow period instead of leaving soil bare (Panagosa et al. 2015) and when implementing practices decreasing soil disturbance like relay cropping (Fig. 3). Several factors explain the decreased erosion observed under vegetation cover (Zuazo and Pleguezuelo 2009):

- $\quad$ Rain interception by the canopy and by plant liter on the soil surface protects the soil physically.

- Development of permanent root systems in shallow and deeper soil layers helps maintain soil stability and decrease particle losses.

- Higher SOM content in the topsoil increases soil aggregate stability.

- Higher soil porosity, related to the higher SOM content and biological activity (particularly earthworms; Lamande et al. 2003) below pastures, increases soil water infiltration, thus reducing water runoff (Carroll and Tucker 2000).

- Canopy roughness decreases detachment and transfer of soil particles by the wind.

For these reasons, soil erosion decreases exponentially with increasing plant cover (Gyssels et al. 2005) and decreased soil disturbance, which is promoted over time by integrating ley pastures into arable and mixed systems, regardless of pasture use as long as overgrazing and trampling are avoided (Fig. 3). In England, Fullen (1998) found that under developed ley pastures, erosion rates were limited to $0.1-0.5 \mathrm{t} / \mathrm{ha} /$ year against $11.3 \mathrm{t} / \mathrm{ha} /$ year for bare arable soils. In the Chinese Loess plateau, which is highly susceptible to soil erosion, runoff on fields planted with alfalfa (Medicago sativa) and Caomuxi (Melilotus suaveolens Ledeb, a biennial forage) was limited to $13.0 \mathrm{~mm}$ against $81.0 \mathrm{~mm}$ for cropland leading to sediment losses by 4.6 and $40.6 \mathrm{t} / \mathrm{ha} /$ year, respectively (Jun et al. 2010). This trend was confirmed on sloppy $\left(>25^{\circ}\right)$ croplands of the Loess plateau converted into forests and pastures leading to an estimated decrease of soil erosion from 85 to $55 \mathrm{t} / \mathrm{ha} /$ year although the latter remains extremely high (Fu et al. 2011). A decrease in soil erosion decreases loss of soil nutrients, particularly nitrogen $(\mathrm{N})$ and phosphorus (P) (Franzluebbers 2008), thereby decreasing crop productivity losses and damage to the environment (e.g., eutrophication).

\subsection{Nutrient provision and recycling}

Soil microorganisms control a large part of $\mathrm{C}, \mathrm{N}$, and $\mathrm{P}$ cycles in arable and pasture soils (Recous et al. 2017). Their biodiversity and activity are higher in soils with less disturbance (van Eekeren et al. 2008), such as those under ley pastures especially if sown with relay cropping, than in soils with frequent tillage, such as those under annual crops sown on bare soils (Fig. 3). Moreover, introduction of ley pastures into 


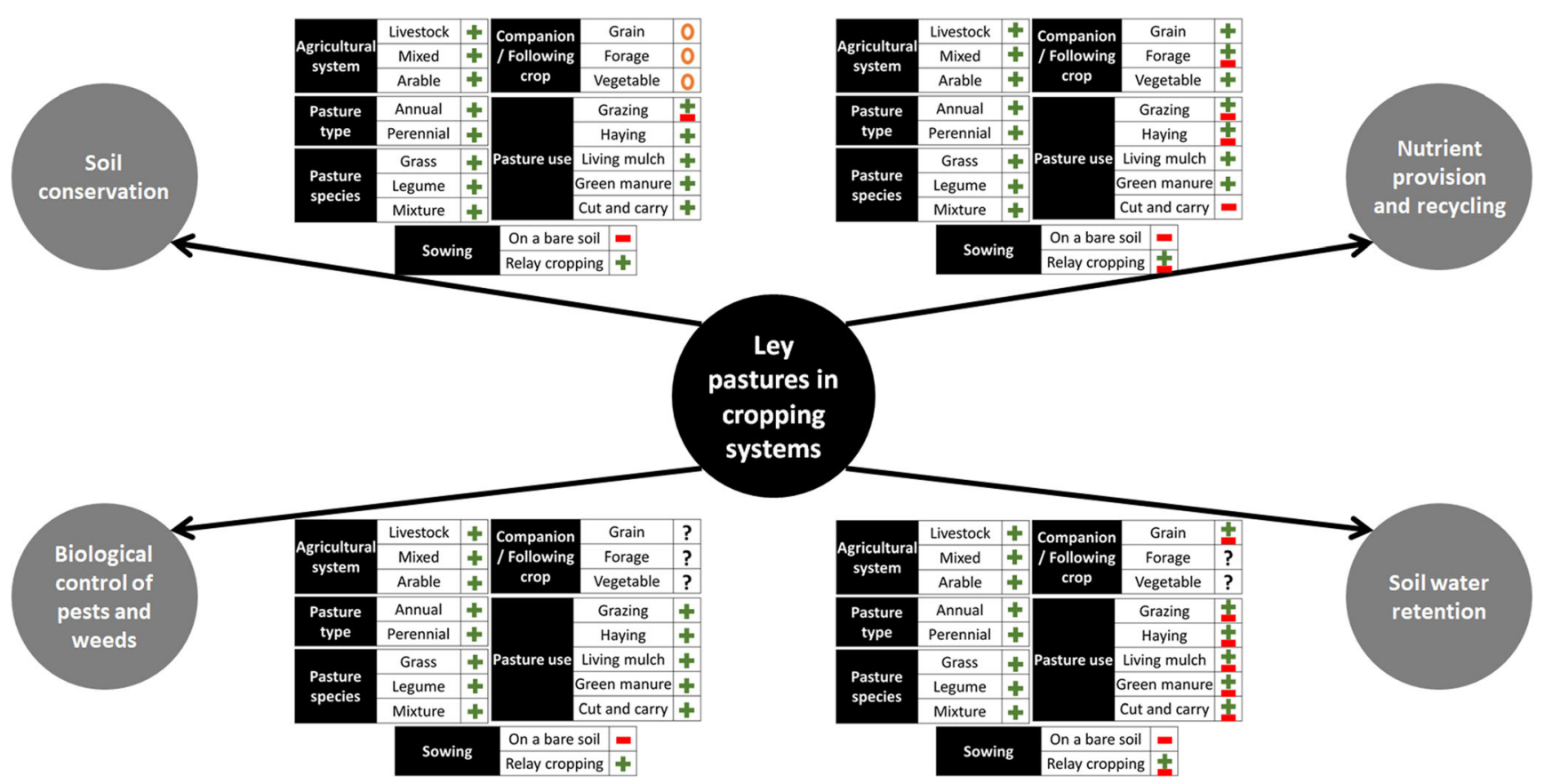

Fig. 3 Synthesis of the effects of introducing ley pastures in cropping systems on input ecosystems services according to the management options considered in this review. Symbols have the following meaning: known positive effects (plus sign), known negative effects

cropping systems of arable and mixed farms can increase provision of soil nutrients via three main mechanisms:

- Higher $\mathrm{N}$ inputs due to symbiotic $\mathrm{N}_{2}$ fixation by legume species sown in pastures, which promotes the cropping system's self-sufficiency in $\mathrm{N}$ and provides high-quality animal feed (Peyraud et al. 2014): $\mathrm{N}$ fixation varies from 30 to $40 \mathrm{~kg} \mathrm{~N} / \mathrm{ha} /$ year in short-duration ley pastures up to more than $300 \mathrm{~kg} \mathrm{~N} / \mathrm{ha} /$ year for well-established alfalfa (Medicago sativa) and clover (Trifolium pratense) stands (Anglade 2015; Rasmussen et al. 2012).

- Greater root development than that under annual crops (corresponding to ca. 30-40\% of C inputs), secretion of more root exudates, and greater development of soil microorganisms including fungi, which desorb $\mathrm{P}$ and potassium (K) (Recous et al. 2017).

- Large $\mathrm{C}$ inputs by grasses and increased decomposition through earthworm, insect, and microorganisms activity, which helps improve soil structure (see section 3.1), recycle urine patches and spread dung and its nutrients (Rumpel and Chabbi 2018; Vertès et al. 2018).

In pastures, organic matter from dead plant organs, both above- and belowground, as well as urine and dung patches if animals grazed in mixed and livestock farms, result in high $\mathrm{C}$ and $\mathrm{N}$ inputs to soils (Rumpel and Chabbi 2018). Some of these inputs are organized as stable organic matter (mean $\mathrm{C}$ storage of $770 \mathrm{~kg} \mathrm{C/ha/year,} \mathrm{ca.} 80 \mathrm{~kg} \mathrm{~N} /$ ha/year; Klumpp and Fornara (minus sign), known as a non-key factor (0), unknown effect (question mark), and positive or negative effect depending on management (plusminus sign)

2018) or remain particulate organic matter. Pellerin et al. (2019) highlight the uncertainties and variability in $\mathrm{C}$ storage under pastures reported in the literature. The longer the duration of ley pasture within a crop sequence, the greater is its influence on soil organic $\mathrm{C}$ (SOC) storage and mitigation of $\mathrm{N}$ losses to the environment. Direct recycling of $\mathrm{N}, \mathrm{P}$, and $\mathrm{K}$ accumulated in pastures is high with grazing, since herbivores do not convert nutrients into protein or animal products efficiently. A grazing dairy cow excretes $34 \%$ of $\mathrm{C}$ intake and $62 \% \mathrm{P}$ intake, mainly through dung, and $70 \%$ of $\mathrm{N}$ intake and $93 \%$ of $\mathrm{K}$ intake, mainly through urine (Vertès et al. 2018). However, animal excretion also depends on pasture management, especially livestock stocking rate during grazing. As stocking rate increases, $\mathrm{C}-\mathrm{N}$ decoupling by animals can progressively offset the $\mathrm{C}-\mathrm{N}$ coupling capacity of the soil-plant system, leading to losses through nitrate $\left(\mathrm{NO}_{3}\right)$ leaching (contributing to eutrophication) and nitrous oxide $\left(\mathrm{N}_{2} \mathrm{O}\right)$ emissions (contributing to climate change) depending on the season and soil conditions (Decau et al. 2003; Leterme et al. 2003; Vertès et al. 2008). The same trade-off may apply with haying according to the $\mathrm{N}$ fertilization level (Fig. 3).

Impacts of emerging uses of ley pastures on nutrient provision and cycling have not been much studied to date and require further research; nonetheless, they impact these processes greatly. Using ley pastures in "cut and carry" systems or to produce bioenergy compromises on-field recycling of nutrients since the nutrients are exported (Fig. 3). Undersowing wheat in living mulches of red fescue (Festuca rubra), sheep's fescue (Festuca ovina), alfalfa (Medicago 
sativa), bird's-foot trefoil (Lotus corniculatus), black medic (Medicago lupulina), and white clover (Trifolium repens) can increase competition for N (Carof et al. 2007b), thereby affecting nutrient provision but promoting internal recycling. In contrast, a living mulch of alfalfa can be the main source of $\mathrm{N}$ for cereals in low-input cropping systems, as practiced by some farmers in France. Amossé et al. (2013a) showed that none of four relay-intercropped legumes (black medic/ Medicago lupulina, alfalfa/Medicago sativa, red clover/ Trifolium pratense and white clover/Trifolium repens) affected $\mathrm{N}$ uptake of an associated winter wheat. Instead, the legume increased $\mathrm{N}$ uptake of the following crop (i.e., maize or spring wheat) and induced a $30 \%$ increase in grain yield.

When pastures are killed, much of the SOM is mineralized, leading to high $\mathrm{C}$ losses (as carbon dioxide $\left(\mathrm{CO}_{2}\right)$ ) and release of mineral $\mathrm{N}$ in soils (Vertès et al. 2007; Necpalova et al. 2014). In addition to basal SOM mineralization, the additive (due to pasture destruction) amount of soil mineral $\mathrm{N}$ available for the following crop varies from 20 to more than $120 \mathrm{~kg} \mathrm{~N} /$ ha (COMIFER 2011) depending on the species sown, pasture use and pasture age when killed (the older the pasture, the more mineral $\mathrm{N}$ available; Vertès et al. 2007; van Eekeren et al. 2008). However, this high $\mathrm{N}$ mineralization can generate large $\mathrm{N}$ losses as leached $\mathrm{NO}_{3}$ and denitrified $\mathrm{N}_{2} \mathrm{O}$ (Vertès et al. 2007; Crème et al. 2018) if the following crop's $\mathrm{N}$ requirements and ability to develop an efficient root system sufficiently early (e.g., with cereals, vegetables and some annual forage crops such as silage maize) are lower than the $\mathrm{N}$ mineralized from SOM and ley pasture residues.

\subsection{Soil water retention}

Water retention in soil depends on runoff and on the soil's ability to retain infiltrated water. Whatever the type of agricultural system, multiannual and short-duration ley pastures physically impede water flow, which decreases runoff and increases water infiltration. For example, on the Chinese Loess plateau, alfalfa stands reduced the velocity of water flows and in turn increased the soil infiltration capacity by 1.77 times compared to bare soils (Wu et al. 2011). Infiltration capacity is influenced mainly by biotic processes, especially SOM content; root biomass; and earthworm presence, biomass, and activity.

Under continuous arable cropping on Australian clay soils, soil hydraulic conductivity decreased exponentially over time but it displayed a fourfold and rapid (within 2-4 years) increase when ley pastures were introduced in the rotation (Silburn et al. 2007). On Chinese mine soils, mixed-species pastures (grasslegume or legume-shrubs) produced more root biomass than pure (i.e., single-species) stands, thus increasing soil infiltration as compared to a bare soil $(-0.59$ vs. 1.48 with soil infiltration assessed through a composite index of soil water infiltration rate over time; $\mathrm{Wu}$ et al. 2016). Comparing pasture subplots with different plant species, functional group richness, and composition (e.g., legumes, grasses, small forbs, tall forbs), Fischer et al. (2014) observed that earthworm presence significantly increased infiltration in summer, while in autumn, effects of grasses and legumes on infiltration were due to plant-mediated changes in earthworm biomass. These hydrological properties vary depending on the duration of ley pastures in crop sequences, since earthworm abundance may increase over time. Anecic earthworm populations were around 3 times larger after 3 years of ley pasture than after 1 year of ley pasture and winter rye on a sandy loam soil (Lamande et al. 2017), also related to the absence of soil tillage during this period. Conversely, pasture harvest (in the case of haying and "cut and carry"), destruction (in the case of green manure), or grazing can decrease water infiltration by compacting the soil (Fig. 3; Franzluebbers et al. 2012).

SOM stored during the pasture period and dead roots left in the soil, by favoring soil stability, increase available water capacity and water infiltration and retention, thus decreasing surface runoff. Those positive effects of ley pastures on soil hydraulic conductivity could be mainly due to changes in SOM (Obour et al. 2018) that improve soil structure. As demonstrated by Zhao et al. (2013) on long-duration pastures in a natural restoration experiment (6-, 16-, 36-, 56-, and 79-year treatments), an increase in SOM in a cropland converted into a 6-year-old pasture $(13.4 \mathrm{~g} / \mathrm{kg}$ vs. $17.5 \mathrm{~g} / \mathrm{kg})$ led to a strong increase in soil infiltration rates (from 39.3 to $52.2 \mathrm{~mm} / \mathrm{h}, 30.2$ to $55.4 \mathrm{~mm} / \mathrm{h}, 27.0$ to $62.4 \mathrm{~mm} / \mathrm{h}$ at low-, medium-, and highintensity rainfall, respectively). This effect explains why soil infiltration rates decrease after conversion of pastureland to cropland (Sun et al. 2018). This decrease also relates to tillage frequency: tillage every 4 years in crop sequences including ley pastures decreased only earthworm abundance, while tillage every year in arable-crop sequences decreased both their abundance and functional diversity (Lamande et al. 2003).

However, ley pastures may also have negative effects on soil water retention. Overgrazing and trampling by animals or tractors (at pasture harvest or destruction) on ley pastures in either arable, mixed, or livestock farms can decrease significantly water infiltration rate to only $10-15 \%$ of that in nontrampled pastures (Pietola et al. 2005). Also, Kunrath et al. (2015) observed that soil dried out more rapidly under pastures than crops. In southwestern France, Tribouillois et al. (2018) showed that, compared to bare soil, cover crops, including some in the form of ley pastures (e.g., Italian ryegrass/ Lolium multiflorum, vetch/Vicia sativa), increased evapotranspiration by a mean of $20 \mathrm{~mm} / \mathrm{year}$ and accordingly decreased water drainage by $21 \mathrm{~mm} /$ year. Conversely, cover crops induced a decrease in soil evaporation proportional to their biomass, due to greater soil coverage. Ultimately, when well managed (e.g., killed on time), cover crops did not decrease the water available to the following cash crops. This conclusion may apply especially to summer crops in temperate climates, in which the effective rainfall (rainfall minus evapotranspiration) generally exceeds soil available water capacity. 
The seedlings of cereal crops sown in a living mulch of ley pasture may have difficulty competing for water with the pasture plants, while the opposite may occur when pasture plants are undersown in a cover of cereals (Fig. 3).

\subsection{Biological control of pests and weeds}

Crop diversification is a key component of agroecological pest management (Liebman and Dyck 1993; Liebman and Gallandt 1997; Colbach et al. submitted). Diversification in time allows farmers to alternate (i) host and non-host crop species, thus reducing pest survival (e.g., Colbach et al. 1994), and (ii) growing seasons, potentially exposing pests to unfavorable growth conditions (e.g., Chauvel et al. 2001). Diversification in space allows farmers to alternate host and non-host crop species within a field, thus reducing pests' ability to find suitable hosts or environments (Finckh et al. 2000; Hiddink et al. 2010; Petit et al. 2018). In addition to these general benefits, specifically introducing ley pastures into cropping systems based mainly on annual crops is a powerful mechanism for managing pests.

For weeds, the ley pasture period provides particularly unfavorable growth conditions regardless the type of agricultural system, for several reasons (Meiss et al. 2010c):

- Plants in pastures compete intensely and almost continuously for light, water, and nutrients (due to canopy closure, rapid regrowth of forage crops after haying, and deep and dense rooting) (Gosse et al. 1988; Meiss et al. 2008).

- Disturbances caused by regular cutting (either for haying in livestock and mixed farms or cut and carry in arable farms) or grazing throughout the year may compromise the ability of weed species to regrow (Norris and Ayres 1991; Hiltbrunner et al. 2008; Meiss et al. 2008).

- Absence of soil tillage and presence of permanent plant cover may form a weed-suppressing mulch, while favoring decomposition and predation of weed seeds (see section 3.5) (Westerman et al. 2005; Heggenstaller et al. 2006; Meiss et al. 2010a).

- Ley pastures with legume species often receive little or no low $\mathrm{N}$ fertilization, thus reducing pressure from weed species with high $\mathrm{N}$ requirements (Andersson and Milberg 1996).

- Some species such as alfalfa (Medicago sativa) and bird's-foot trefoil (Lotus corniculatus) release allelopathic compounds that can inhibit weed growth (Khanh et al. 2005).

- Ley pasture cover can intercept weed seeds, which may decrease replenishment of the soil seed bank (Doisy et al. 2014).

Over the short term (i.e., during the ley pasture period), these factors can influence composition of weed species and reduce their growth. Based on a 12-year study, Schuster et al. (2019) assessed the differences in weed abundance among crop rotations including or not ley pastures established for 3 or 6 years. Crop type (i.e., pasture or cereal) had a strong effect: weed abundance during maize and wheat cropping was on average about three times higher than in ley pastures and barley crops. This study also showed that a cereal crop following 6 years of well-fertilized ley pasture (mix of 3 grass species) had a significantly lower weed abundance, 25-50\% lower than in other rotations (Fig. 3). Beyond pasture management, those authors identified a critical ley pasture biomass of ca. $4.7 \mathrm{t} / \mathrm{ha}$ above which weeds become suppressed in the following year. But at present, this kind of experiment or observations is clearly lacking to quantify ley pasture impacts on weed dynamics.

Short-term effects have delayed impacts over the longer term at the cropping system level by changing the weed seed bank. Generally, following a ley pasture, density of problematic weed species decreases, while overall weed diversity may increase (reviewed by Meiss et al. 2010c), highlighting the role of ley pastures in sustaining plant diversity in agroecosystems (Marshall et al. 2003). Interestingly, weed diversity may increase mainly due to establishment of perennial weed species that are not problematic for annual crops that are tilled (Ominski et al. 1999; Albrecht 2005; Meiss et al. 2010b). For these reasons, cropping systems integrating ley pastures generally have lower herbicide inputs (Lechenet 2017). Effects of ley pastures on weed species can vary depending on the management techniques applied to the ley pastures (e.g., species sown, sowing period, ley pasture duration, haying and/or grazing frequency, and $\mathrm{N}$ fertilization; Fig. 3) (Norris and Ayres 1991; Schuster et al. 2019). Finally, sowing ley pastures as cover crops into a cash crop may help regulate weeds (Amossé et al. 2013a, b; Petit et al. 2018). The challenge is to minimize competition of pasture plants with the cash crop while maximizing their competition with weeds.

Ley pastures have no direct effects on pest populations or diseases. However, indirect effects of ley pastures on them, within the context of manipulating habitats for beneficial organisms and natural enemies, are well described (see Sect. 4.3). For example, based on a unique French national network of arable farms involved in a pesticide-reduction program, Lechenet et al. (2016) highlighted that mixed farms with livestock relied less on pesticides than those without livestock. Indeed, mixed farms combining crops and livestock have more opportunities to diversify crop sequences with ley pastures and forage crops (e.g., silage maize, intercrops, triticale, other secondary cereals), since the presence of livestock provides extra outlets for ley pastures and forage crops. In an additional study, Lechenet et al. (2017) observed that most $(72 \%)$ farms with a significant negative effect of the total Treatment Frequency Index (TFI) on crop productivity 
(indicating a potential productivity gain or no effect associated with a reduction of pesticide use) were mixed farms that had mainly soils with low available water capacity, medium-tohigh yield potentials, and a large proportion of ley pastures and silage maize on their agricultural area. These crops generally had high productivity and low TFI.

\section{Output services provided by ley pastures in cropping systems}

\subsection{Water purification}

In all types of agricultural systems, ley pastures, by covering the soil during periods at risk for deep water contamination (winter in oceanic western Europe), reduce $\mathrm{N}$ leaching through plant uptake of $\mathrm{N}$. Leaching is particularly reduced when hayed pastures with balanced fertilization are introduced into arable-crop sequences (from 37 to $8 \mathrm{~kg} \mathrm{~N} /$ ha/year on average in Kunrath et al. 2015), while leaching under grazed pastures depends largely on stocking rates and pedoclimatic conditions (Fig. 4; Ledgard et al. 2009; Vertès et al. 2008). Risk of $\mathrm{N}$ leaching also varies with the species sown: introducing pastures of perennial forage legumes into arable cropping systems decreases the risk over the crop sequence (Anglade et al. 2015). After a ley pasture is killed, however, if the following crop cannot take up the large amount of $\mathrm{N}$ mineralized in the soil (as is the case with cereals, vegetables and some forage crops such as silage maize without undersown catch crop able to uptake soil mineral $\mathrm{N}$ in autumn and winter), $\mathrm{N}$ leaching is high, ranging from 60 to $250 \mathrm{~kg} \mathrm{~N} /$ ha/year (Vertès et al. 2007). N leaching tends to increase with pasture age, autumn plowing, previous high fertilization rates on the pasture, a large proportion of legumes, and/or high stocking rates during grazing. Denitrification resulting in $\mathrm{N}_{2} \mathrm{O}$ emissions also tends to increase after pasture plowing (Davies et al. 2001).

The influence of ley pastures on decreasing $\mathrm{P}$, chemical oxygen demand, and pesticides in water has not been studied to date. Still, since pastures are not usually treated for pests (Lechenet et al. 2017), integrating them into cropping systems results in lower pesticide inputs over an entire crop sequence, whatever the agricultural system and pasture use (Fig. 4). Moreover, water purification results from a variety of processes such as nutrient uptake by plants, adsorption of elements on SOM and mineral elements, biotic and abiotic transformations, and gaseous emissions that allow trends of the influence of ley pastures on this ecosystem service to be deduced. In a rare study of dissolved organic carbon (DOC), Kindler et al. (2011) showed little difference in mean DOC concentration in topsoil or DOC leaching between pastureland and cropland $\left(5.3 \pm 2.0\right.$ and $4.1 \pm 1.3 \mathrm{~g} / \mathrm{m}^{2} /$ year, respectively $)$. More research is required to better estimate the influence of faster drainage on DOC leaching, especially since Brye et al. (2001) reported a fivefold increase in DOC leaching for 4 years after conversion of native tall-grass pasture to maize

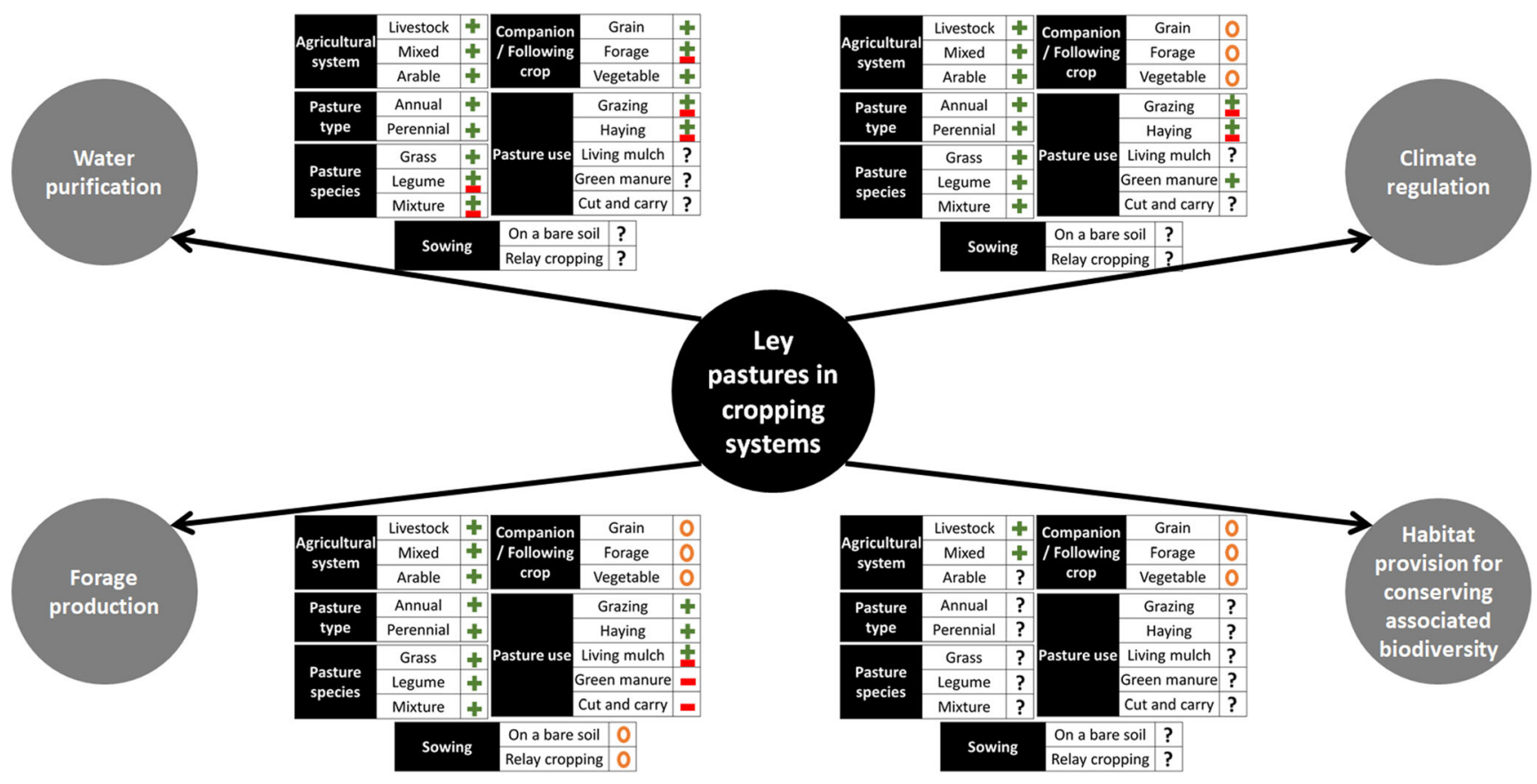

Fig. 4 Synthesis of the effects of introducing ley pastures in cropping systems on output ecosystems services according to the management options considered in this review. Symbols have the following meaning: known positive effects (plus sign), known negative effects

(minus sign), known as a non-key factor (0), unknown effect (question mark), and positive or negative effect depending on management (plusminus sign) 
cultivation. In addition, ley pastures promote pesticide retention and degradation through biotic and abiotic processes (Parkin 1993), depending on the soil's ability to adsorb pesticides from the soil solution, adsorb them to the soil matrix, and degrade them. SOM can adsorb pesticides and favor degraders of organic compounds, thus improving filtering capacity. Thus, an increase in SOC such as that during the ley pasture period improves the soil's general ability to filter organic pesticides. Soil bioturbation by earthworms, which are abundant below ley pastures, may also influence distribution and degradation of organic compounds such as pesticides (Monard et al. 2008).

\subsection{Climate regulation}

C storage by pastures is an important mechanism to mitigate climate change (Pellerin et al. 2017; Klumpp and Fornara 2018). While there is general agreement on trends in $C$ storage or release, more precise estimates vary widely in the scarce literature focused on cropping systems integrating ley pastures. Converting cropland into pastureland results in $\mathrm{C}$ storage for several years (Don et al. 2009; Johnston et al. 2017). Metaanalyses have estimated a few annual storage rates $(\mathrm{Mg} \mathrm{C} / \mathrm{ha} /$ year) in the topsoil $(0-30 \mathrm{~cm}): 0.54$ (Conant et al. 2001), and 0.60 over 30 years (Loiseau and Chevallier 2002). In a study analyzing conversion to pastureland and "deconversion" to cropland, Poeplau et al. (2011) predicted mean C storage and release rates of $0.92 \pm 0.25$ and $2.08 \pm 0.26 \mathrm{Mg} \mathrm{C} /$ ha/year, respectively, over 20 years.

The rate of $\mathrm{C}$ storage or release is known to vary with pasture age (Franzluebbers et al. 2000; Johnston et al. 2017; Conant et al. 2001). For the first 2-3 years, a pasture stores $C$ in the topsoil due to C input (Whitehead et al. 1990) and then begins to store it in deeper soil layers (Rumpel and Chabbi 2018). Similarly, the rate of $C$ release decreases quickly after the pasture is killed, with losses of $50-80 \%$ of the initial C stock (Guo and Gifford 2002; Lal 2008). Little literature is available that describes effects of ley pasture duration on soil $\mathrm{C}$ dynamics. A long-term experiment on a soil with high initial $\mathrm{C}$ stock ( $90 \mathrm{t} \mathrm{C} /$ ha from 0 to $25 \mathrm{~cm}$ ) compared SOC dynamics under 48-month maize-pasture crop sequences including 6, 12,18 , and 42 months of grass-based ley pastures: in all cases, SOC decreased at a rate inversely proportional to pasture duration (Vertès and Mary 2014, 2007), as also shown by Rumpel and Chabbi (2018). Even in soil with high initial C content and a hayed pasture (which inputs less $\mathrm{C}$ to the soil than grazed pasture), only the crop sequence with 42 months of pasture and 6 months of maize strongly limited the decrease in $\mathrm{C}$ stock ( $-5 \%$ over 27 years), as modeled by Dollé and Klumpp (2015), who suggested that 7-year ley-arable crop sequences should have ley pastures for at least 3 years to keep SOM stock stable. This is however highly dependent on initial $\mathrm{C}$ stock and on other organic matter management implemented in the arable phase (tillage practices, presence/ absence of cover crops, management of crop residues, and fertilization practices). Clivot et al. (2019) and Constantin et al. (2010) found lower soil C and $\mathrm{N}$ release, respectively, when integrating ryegrass (Lolium sp.) cover crops in arable cropping systems than when leaving soil bare during winter $(-30 \%$ and $-22 \%$ of initial C stock, respectively). However, since the rate of $\mathrm{C}$ storage decreases with increasing $\mathrm{C}$ stock (Minasny et al. 2017), ley pastures and cover crops are expected to be able to store more $\mathrm{C}$ per year than permanent grasslands (Pellerin et al. 2019). Little literature is available that describes effects of the species sown on $\mathrm{C}$ storage (Fig. 4; Lange et al. 2015), although $C$ storage may be higher under species-rich mixtures (Skinner and Dell 2016). After 4 years, Steinbeiss et al. (2008) reported increases in carbon stocks in the complete plow horizon by nearly $50 \%$ and by more than $100 \%$ when moving from 1 to 2 species sown and from 1 to 16 species sown, respectively.

Although little is known about impacts of emerging uses of ley pastures (e.g., living mulch, cut and carry), traditional uses (mainly grazing and haying) may counteract positive effects of pastures on climate-change mitigation (Fig. 4), especially in livestock and mixed farms as ruminants are high contributors to greenhouse gas emissions trough methane emissions from enteric fermentation in their rumen. Those methane emissions are mainly related to the digestibility of ingested feed (Sauvant et al. 2011) which is usually high (75-80\%) in grazed grass, lower in silage maize or grass silage (70-72\%), and lower in late hay and poor feeding quality grasslands (INRA-CIRADAFZ 2018). Ingestion rates also vary with animal needs and feed quality. Thus, the contribution of ruminants to greenhouse gas emissions varies with animal management especially feeding management (Basset-Mens et al. 2009), and results depend on the functional units used (per unit mass of animal product, per ha, per produced value; Salou et al. 2017). Emissions related to other types of pasture use (e.g., living mulch) have not been extensively documented to date. In presence of living mulch, Bartel et al. (2017) found decreases in maize yield from 23 to $73 \%$ and subsequently decreases in ethanol yield from 12 to $119 \%$ leading to higher emissions per unit mass of product and per hectare. Kura clover (Trifolium ambiguum M. Bieb.) living mulch in corn-soybean systems increased $\mathrm{N}_{2} \mathrm{O}$ emissions (from 131.3 to $226.5 \mathrm{mg} \mathrm{N} / \mathrm{m} 2$ on year 1 and from 72.8 to $161.3 \mathrm{mg} \mathrm{N} / \mathrm{m} 2$ on year 2) even with a $43 \%$ reduction of $\mathrm{N}$ fertilizer application rate (Turner et al. 2016). However, the use of living mulch might reduce nitrate leaching and result in lower indirect (offsite) $\mathrm{N}_{2} \mathrm{O}$ emissions. When including other activities of pasture-based dairy cattle systems such as storage, processing, and application of manure, no clear trends in greenhouse gas emissions emerge from comparisons with those of maize-soybean dairy cattle systems. Life cycle assessments on the topic (Thomassen et al. 2008; Nguyen et al. 2013a, b) estimated high variability 
in climate-change impacts depending on the main features of the production system (e.g., grazing management, presence/ absence of crops and cover crops, cow productivity) and the functional unit used.

Finally, since bare soil generally has lower albedo than vegetation, using ley pastures as cover crops (for several months) in arable crop farms or long-term cover (for several years) in mixed or livestock farms could help mitigate climate change (Fig. 4). Carrer et al. (2018) recently estimated that introducing 3-month cover crops to $4.2 \%$ of the EU-28's area, corresponding to $22 \%$ of its agricultural area, would provide a mitigation potential of $3.16 \mathrm{Mt} \mathrm{CO}_{2}$-eq/year. This albedorelated mitigation potential corresponds to $0.74 \%$ of the EU28's annual agricultural greenhouse gas emissions (reference year: 2011), which would be added to the mitigation potential of soil $\mathrm{C}$ storage. This mitigation potential could increase by $27 \%$ if cover crops lasted longer than 3 months but decrease by $28 \%$ if no irrigation were used to support cover crop emergence. These initial results indicate that effects of ley pastures on soil water flows and albedo must be considered jointly in future research.

\subsection{Habitat provision for conserving associated biodiversity}

The vast expansion and extreme intensification of agriculture is one of the major drivers of natural habitat fragmentation and loss of farmland biodiversity (Wade et al. 2007; Lu et al. 2014), especially of natural enemies and pollinators (Meyer et al. 1992; Benton et al. 2003; Tscharntke et al. 2005). These negative consequences have been in the spotlight recently, with studies claiming that $40 \%$ of world insect species are threatened with extinction due to current agricultural practices (Hallmann et al. 2017; Habel et al. 2019; Sánchez-Bayo and Wyckhuys 2019). Ley pastures have a key role to play in the redesign of agricultural systems in order to maintain and improve biodiversity and populations of species, especially endangered species and organisms used for biocontrol such as natural enemies of pests (Stuhldreher et al. 2012).

It is widely accepted that both ley and semi-natural pastures play a vital role in maintaining biodiversity in many agricultural areas since they provide overwintering sites, food resources, refuges, and source populations for recolonization of disturbed habitats (Tscharntke et al. 2005; ChaplinKramer et al. 2011). There is increasing evidence that ley pastures may support many arthropod species, birds, small mammals, and vascular plants (Benton et al. 2003; Burel et al. 2004; Hendrickx et al. 2007; Billeter et al. 2008; Duflot et al. 2014). Likewise, populations of many species, including the blue spot hairstreak butterfly (Satyrium spini) in the Spanish Pyrenees, the marsh fritillary butterfly (Euphydryas aurinia), and butterfly orchid (Platanthera chlorantha) in Culm pastures in the UK (Gardiner et al.
2005) and common starlings in Europe (Smith and Bruun 2002), have declined as the area of permanent pastures has decreased due to land-use change.

When focusing exclusively on impacts of ley pastures on habitat provision and biodiversity conservation, much less scientific literature is available (Fig. 4). Nonetheless, Duflot et al. (2015) observed that landscapes with ley pastures had the same species richness of carabid beetles and vascular plants as those with semi-natural pastures, probably due to similar agricultural practices (e.g., grazing, haying, fertilization, oversowing with desirable plants). Similar results were found for Chironomidae populations in other landscapes (Burel et al. 1998). In contrast, common vole populations had much higher abundance on ley pastures (Delattre et al. 2009). Arthropod abundance and diversity may also depend on the species sown; for example, grasshoppers had lower densities in alfalfa pastures than in other ley pastures (Bretagnolle et al. 2011).

However, it is unclear to date whether reintroduction of ley pastures to intensive arable-crop areas or emerging uses of ley pastures may have similar impacts on conserving associated biodiversity. Moreover, there is also evidence that ley pastures serve as a reservoir for secondary pest infestation, such as wireworms, which can severely damage potato fields (Parker and Howard 2001; Hermann et al. 2013), requiring additional pest control (East and King 1977; Willoughby et al. 1997; Delattre et al. 2009; Vernon and van Herk 2013).

\subsection{Forage production}

Producing forage is of primary interest for feeding ruminants in mixed and livestock farms. The value of forage depends on the quantity and quality of shoot biomass harvested and consumed by animals (Ball et al. 2001). Several factors strongly influence ley pasture productivity, including climate (particularly solar radiation, rainfall, and temperature; Gosse et al. 1986; Jones and Lazenby 1988; Gastal and Durand 2000; Huyghe et al. 2014), botanical composition, soil characteristics, and pasture management, particularly fertilizer application and haying and/or grazing (Lemaire et al. 2000). Official statistics on ley pasture productivity in European countries are lacking (Lee 1988; Smit et al. 2008). The data available come from survey summaries or predictions of pasture-growth simulation models (e.g., Duru et al. 2009; Durand et al. 2010). Pure grass stands have the highest yields in temperate regions of northwestern Europe (latitudes 52-57 $\mathrm{N}$ ) with on average $8-11$ (up to 15 ) t dry matter (DM)/ha/year (Graux et al. 2020) when sufficient nutrients are available. However, pastures rarely receive enough fertilizers to achieve the non-limiting conditions that would maximize biomass production. In southern Europe (Mediterranean countries and southern Portugal), water stress usually limits productivity and can decrease yields to $1-5 \mathrm{t} \mathrm{DM} /$ ha/year or less (Durand 
et al. 2010; Poirier et al. 2012). In all regions of Europe, pure legume stands generally have lower yields than pure grass stands under high $\mathrm{N}$ fertilization, but higher yields than pure grass stands under low N (Nyfeler et al. 2011; Finn et al. 2013). In pure legume stands, alfalfa (Medicago sativa) and red clover (Trifolium pratense) have the highest annual yields: 11-15 t DM/ha/year in favorable temperate areas (e.g., $13 \mathrm{t} \mathrm{DM} / \mathrm{ha}$ for alfalfa in the Champagne-Ardennes region, France from 1980 to 2012; Huyghe et al. 2014). Unirrigated alfalfa has lower yield (Durand et al. 1989), 2.0-5.5 t DM/ha/ year in Mediterranean climates (Julier et al. 2017), and protein content (Lemaire et al. 1989). For both grasses and legumes, potential productivity varies over time: it is lowest during the establishment year, peaks for the 2-3 years that follow, and then often decreases depending on the species (Beuselinck et al. 1994). Consequently, species mixtures often increase the longevity of ley pastures (Capitaine et al. 2008) under low-input management. Mixed-species stands, especially those with grasses and legumes, can achieve higher yields (Capitaine et al. 2008; Nyfeler et al. 2009). Mixed-species stands commonly "overyield" (i.e., produce more yield than those of pure stands of each species in the mixture) in all climates by up to $0.5-4.0 \mathrm{t} \mathrm{DM} / \mathrm{ha} / \mathrm{year}$ (Finn et al. 2013). Forage production by pastures can also produce bioenergy (66-119 GJ/ha/year, depending on pasture type and soil depth) (Rösch et al. 2009).

Forage quality aggregates effects of ingested forage on animal performance (Ball et al. 2001). It encompasses forage nutritive value (i.e., digestibility and nutrient contents) as well as indigestibility and anti-quality factors (i.e., compounds that can lower animal performance, such as tannins, alkaloids, cyanoglycosides, phytoestrogens, and mycotoxins). The feed value of forages is closely related to their botanical composition (grass, legume, and forb proportions), yield, maturity stage and organ composition at harvest, and pasture management, especially fertilization. For all types of ley pasture, forage digestibility and biochemical composition vary throughout the year (generally lower in summer; see Lemaire et al. (1989) for alfalfa digestibility) and as a function of plant growth (Lemaire et al. 1989; Ducrocq and Duru 1996; Duru et al. 2008). Forage digestibility decreases as plant tissues age, related to phenology. The proportion of structural organs increases with plant age (e.g., decreasing leaf-to-stem ratio, increasing proportion of reproductive organs; Lemaire et al. 1989; Duru et al. 2008), decreasing contents of digestible compounds (e.g., crude protein, soluble sugars) and increasing fiber content. Accordingly, forage digestibility usually decreases linearly with plant age and allometrically with yield (Duru et al. 2008; Gastal et al. 2015). From early to late growth stages, forage digestibility decreases from 750 to $400 \mathrm{~g} / \mathrm{kg}$, respectively, in alfalfa (Lemaire et al. 1989) and from 800 to $550 \mathrm{~g} / \mathrm{kg}$, respectively, in cocksfoot under high $\mathrm{N}$ fertilization (Duru et al. 2008). For a given productivity level, legumes usually have higher crude protein content than grasses but lower energy content. Grass species and varieties of different productivity levels can also differ in digestibility for a given yield (Baumont et al. 2007). Finally, species mixtures generally have a more adequate protein:energy ratio than pure species do (Baumont et al. 2008) due to complementarities in their compositions that make the mixture slightly more digestible than the weighted average of each species (Brown et al. 1991).

\section{Which diversity of ley pastures for tomorrow's cropping systems?}

\subsection{Pasture species composition}

A pasture may contain one (pure stand), two (association or binary mixtures), or multiple species (complex mixtures or multispecies pastures). Pure species pastures have been sown widely since the 1960s to secure the nature, amount, and composition of harvested forage, as long as fertilizers and/or herbicides could be applied.

Mixtures of perennial grass and legume species are considered essential to provide ecosystem services (Fig. 1) under lowinput management (Porqueddu et al. 2016; Lemaire et al. 2015). Grasses and legumes form two complementary functional groups (Roscher et al. 2004): legumes can fix atmospheric $\mathrm{N}$ through symbiosis, while grasses absorb $\mathrm{NO}_{3}$ efficiently and have higher productivity. Achieving balance between species, and especially persistence of legumes over several years, is key (Kirwan et al. 2007). A legume proportion of 0.3-0.7 is considered the most effective for producing $\mathrm{N}$ to maximize yield (Nyfeler et al. 2011). Species within each functional group have contrasting traits related to factors such above- and belowground growth, earliness, and chemical composition (Roscher et al. 2004). Since taller species may outcompete shorter species for light, mixtures usually combine species of similar potential height, either tall (e.g., alfalfa/Medicago sativa, red clover/ Trifolium pratense, cocksfoot/Dactylis glomerata, tall fescue/ Festuca arundinacea) or short (e.g., white clover/Trifolium repens, perennial ryegrass/Lolium perenne, timothy/Phleum pratense, smooth meadow grass/Poa pratensis). Water and mineral acquisition also depends on root depth and architecture (Gastal et al. 2010). Although plant architecture shows plasticity, the rooting system of forage species is described as deep (e.g., alfalfa, tall fescue), intermediate (e.g., red clover/Trifolium pratense, perennial ryegrass/Lolium perenne), or shallow (e.g., white clover/Trifolium repens, cocksfoot/Dactylis glomerata) (Gastal et al. 2010). Mixing species with different rooting depths increases exploration and exploitation of soil resources (Gastal et al. 2010). Because growth dynamics of grasses and legumes differ after sowing, after haying and among seasons, grasslegume mixtures cover the soil throughout the year and thus provide weeds with less opportunity to develop than pure stands (Helgadottir et al. 2018; Hayes et al. 2018) and limit soil erosion 
(Porqueddu et al. 2016). The species selected for multiservice pastures must be adapted to specific soil, management, and climatic constraints (Frick et al. 2008; Lüscher et al. 2017).

The optimal number of species in ley pastures is controversial. Species richness has long been recognized as a key driver of pasture productivity (Hector and Hooper 2002, citing Darwin 1858). Increasing species richness in a pasture stabilizes biomass production over time (Gross et al. 2014) and in space (Weigelt et al. 2008). These advantages emerge from species traits and species interactions. Species' functional traits, especially $\mathrm{N}$ acquisition and use, explain biomass production better than species richness (Buchmann et al. 2018). Maximizing rooting depth and root distribution by selecting species adapted for the pasture is a priority to increase water uptake throughout the soil profile (Barkaoui et al. 2016). Pasture species diversity has been shown to influence the habitat provision service, with more diverse pastures having greater diversity in above- or below-ground organisms (Schaffers et al. 2008, 2010) and lower susceptibility to biological invasion or pathogen infestation. As for biomass, damages caused by insect or mollusk herbivory are related more to species traits than to species richness (Scherber et al. 2006).

The EU authorized the sale of seeds of species mixtures for forage production in 2004 (Commission Decision 2004/371/ EC); since then, all seed companies have developed mixtures for specific uses. The species chosen for sowing in a new pasture is key. General rules have been established to benefit from complementarity and decrease competition between species. The need to choose at least one grass and one legume species emerges from their complementarity in N-use efficiency. Since competition and complementarity between the species chosen interact with forage use by animals and local conditions of soil, climate, and management, expert systems have been developed to help farmers choose the most adapted mixtures (AFPF 2017a, b; Frick et al. 2008; Goutiers et al. 2016; Lüscher et al. 2017). Recently, detailed ecophysiological models have helped decipher the influence of complex interactions of environmental variables on mixed-species yield and quality (Gaudio et al. 2019; Faverjon et al. 2019). More precisely, models can be used to identify important traits to consider when mixing legume and non-legume species to achieve both productivity and stability (Louarn et al. 2018). Such tools could be used for testing yield, quality, and persistence of different species mixtures.

\subsection{Choice of varieties for mixtures}

In the most important forage species, available varieties have been improved for forage yield, forage quality, abiotic stress (mainly frost), and biotic stress (diseases). Farmers choose varieties because of their adaption to different climates or uses, based on their autumn dormancy (for alfalfa/Medicago sativa) or flowering earliness (for grasses) (Annicchiarico et al. 2015;
Humphreys et al. 2006). Recently, traits related to adaptation to climate change and reduced inputs such as tolerance to drought (Ergon et al. 2018), low $\mathrm{NO}_{3}$ fertilization for grasses (Pembleton et al. 2016), low P fertilization (Lopez-Arredondo et al. 2014), and competition with weeds (Annicchiarico and Pecetti 2010; Dear and Ewing 2008) have been identified, but their consideration in breeding programs requires costly phenotyping. Stand persistence, a trait that contributes not only to forage production but also indirectly to soil conservation is considered, but it is difficult to assess when the release of genetic progress (i.e., new traits exhibiting in the field) requires a minimum duration of experiments (usually 3 years).

For many traits (e.g., resistance, quality), the genetic progress achieved for pure stands is probably also useful when two or more species are mixed, with one or more varieties of each species. However, several results show that pure stands have different hierarchies of traits than mixtures (Maamouri et al. 2017). For example, lodging resistance is a major trait of interest in alfalfa (Medicago sativa) grown in pure stands, but alfalfa almost never lodges when it is grown in mixtures with grasses; thus, the focus on lodging resistance can be relaxed. Properties that emerge from grass-legume mixtures (e.g., $\mathrm{N}$ fixation and recycling (Louarn et al. 2018), weed and pest control, forage quantity and quality with low inputs) are determined by plant traits that should be selected for, in a view to breed new varieties specifically adapted to forage-species mixtures. Classes of aggressiveness or compatibility, such as those based on leaflet size in white clover, could be defined and used to reduce the number of variety mixtures. In addition, like for species choice, ecophysiological models could be used to design new ideotypes characterized by average trait values (Louarn et al. 2018). In a view to breed new varieties, populations with appropriate traits for breeding new varieties could thus be virtually pre-selected to reduce the otherwise large number of mixtures to assess in the field.

The degree of within-species genetic diversity in a mixture may also be key. Recent studies strongly suggest that using several varieties per species rather than only one secures yield, stability, and legume proportion in the stand (Meilhac et al. 2019) and increases drought tolerance and persistence of the stand (Prieto et al. 2015). Mixing varieties in multispecies pastures is an additional complexity but a promising way to improve pasture value.

\section{Research agenda}

\subsection{Defining a safe operating space for ley pastures in cropping systems}

To address the challenges of climate change, food security, and human health, agrifood systems require deep change, especially a decrease in livestock production and consumption 
in developed countries (Tilman and Clark 2014). Monogastric animals such as pigs and poultry produce protein more efficiently than ruminants. However, ruminants can be fed from permanent pastureland and wetlands unsuitable for crop production, thus avoiding competition with human food production. On this basis, as mentioned, most future-oriented food system scenarios assume production of fewer ruminant livestock and feeding them only from permanent pastureland and wetlands (Westhoek et al. 2014; Schader et al. 2015; Röös et al. 2017). These scenarios ignore ley pastures or sharply reduce them despite the large set of ecosystem services they provide, including better composition of animal products for human health (Duru et al. 2018) when their spatial and temporal insertion within cropping systems is well-managed. Only Poux and Aubert (2018) considered ley pastures when designing a sustainable European food system scenario called "Ten Years For Agroecology" (TYFA) to feed the European population in 2050. This scenario relies on a profound revision of the human diet, with less protein and a lower proportion of it coming from animal products, no mineral fertilizers or agrochemicals for crop production, and no importation of soybeans. The authors used certified organic farming as a model to design the scenario because a large amount of consolidated data about its performances, especially yield, is already available. In the TYFA scenario, biological $\mathrm{N}$ fixation is the only source of $\mathrm{N}$ input to crops, and much of it is provided by legume-based ley pastures and, to a lesser extent, by grain legumes whose fixed $\mathrm{N}$ is recycled via previous-crop effects or via livestock manure deposited on other crops such as cereals. In the scenario, ley pastures are also assumed to play a central role in biological regulation of pests, thus replacing pesticides. The authors concluded that supplying Europe with healthy food in 2050 would require more equal distribution of pastures in Europe, even in areas specialized in arable cropping. In line with the TYFA scenario, we claim that the role and importance of ley pastures in tomorrow's cropping systems should be reconsidered through an ecologically intensive lens that brings together new technologies and organizations at multiple levels.

To benefit from ecosystem services provided by ley pastures in cropping systems while limiting their disservices to thresholds compatible with international commitments (e.g., greenhouse gas emissions) and/or political choices (e.g., feed/food competition for land use), it appears necessary to define a "safe operating space" (Rockström et al. 2009; Buckwell and Nadeu 2016) for ley pastures in cropping systems. The practical questions are how to identify this safe operating space and how to transition cropping systems into this space. To expand upon this concept, we describe what this space could be, considering only a few services and disservices. As disservices, we considered degrees of feed/food competition for land use (as a \% of total land dedicated to livestock feed production; Fig. 5, $Y$-axis) and greenhouse gas emissions of cropping systems including ley pastures (e.g., crop-livestock farms, cover crops) (as $\mathrm{kg} \mathrm{CO}_{2}$ eq./ha/year; Fig. 5, Y-axis). Greenhouse gas emissions increase as ley pastures are increasingly used to feed livestock. In a scenario in which all arable land is used to produce food, land-use competition begins as soon as arable land is used for ley pastures instead of food crops (Fig. 5, $X$-axis). A threshold is defined for each disservice to represent the sustainability boundary and the levels of disservices are plotted relatively to these thresholds. However, ley pastures provide bundles of ecosystem services such as $\mathrm{N}$ supply (kg N/ha/year), $\mathrm{C}$ storage (kg C/ha/year), and biological regulations allowing to reduce pesticide use (load avoided/ha/year or treatment frequency index reduction in \%) more or less proportionally not only to their relative area but also to their spatial and temporal insertion within cropping systems, up to a known level of maximum benefits. Increases in the provision of services are plotted relatively to each of those levels of maximum benefits. Beyond those points, the relationships may keep increasing, remain stable or even decrease, and eventually become negative (Fig. 5, green triangles). For example, beyond a given area of legume-based ley pastures in cropping systems, $\mathrm{N}$ supply may become excessive and create disservices. The safe operating space for ley pastures in cropping systems is the space located between the maximum level of services observed and the lowest boundary of disservices, here defined by $\mathrm{N}$ supply by legumes and greenhouse gas emissions, respectively (Fig. 5).

The range of the levels of ecosystem services and disservices provided by ley pastures depends mainly on the relative durations of ley pastures within crop sequences in cropping systems (Fig. 5, horizontal arrows) and on pasture management, especially the relevance of their spatial and temporal insertion within cropping systems (Fig. 5, vertical arrows). For example, stocking rates of ley pastures must be adapted to pasture characteristics (e.g., annual or perennial, species sown) and level of intensification (e.g., fertilization, frequency of use). Currently, certain issues need to be addressed to reach the safe operating space for ley pastures in cropping systems. Several environmental factors influence the levels of services and disservices that can be reached. For example, annual pasture productivity is often limited by nutrient availability in temperate European regions. In addition, the probability that sowing will fail has increased in southern Europe due to climate change. Thus, strategies to reach the safe operating space for ley pastures in cropping systems should be defined at the regional level based on regional characteristics (e.g., pedoclimatic conditions, landscape structures).

Currently, defining and moving towards the safe operating space for ley pastures in cropping systems requires (i) adjusting breeding programs to consider multiservice ley pastures (Annicchiarico et al. 2019), (ii) addressing ley pasture management issues that may decrease disservices through better management or use of new technologies (e.g., new varieties and species mixtures), (iii) better quantifying the 


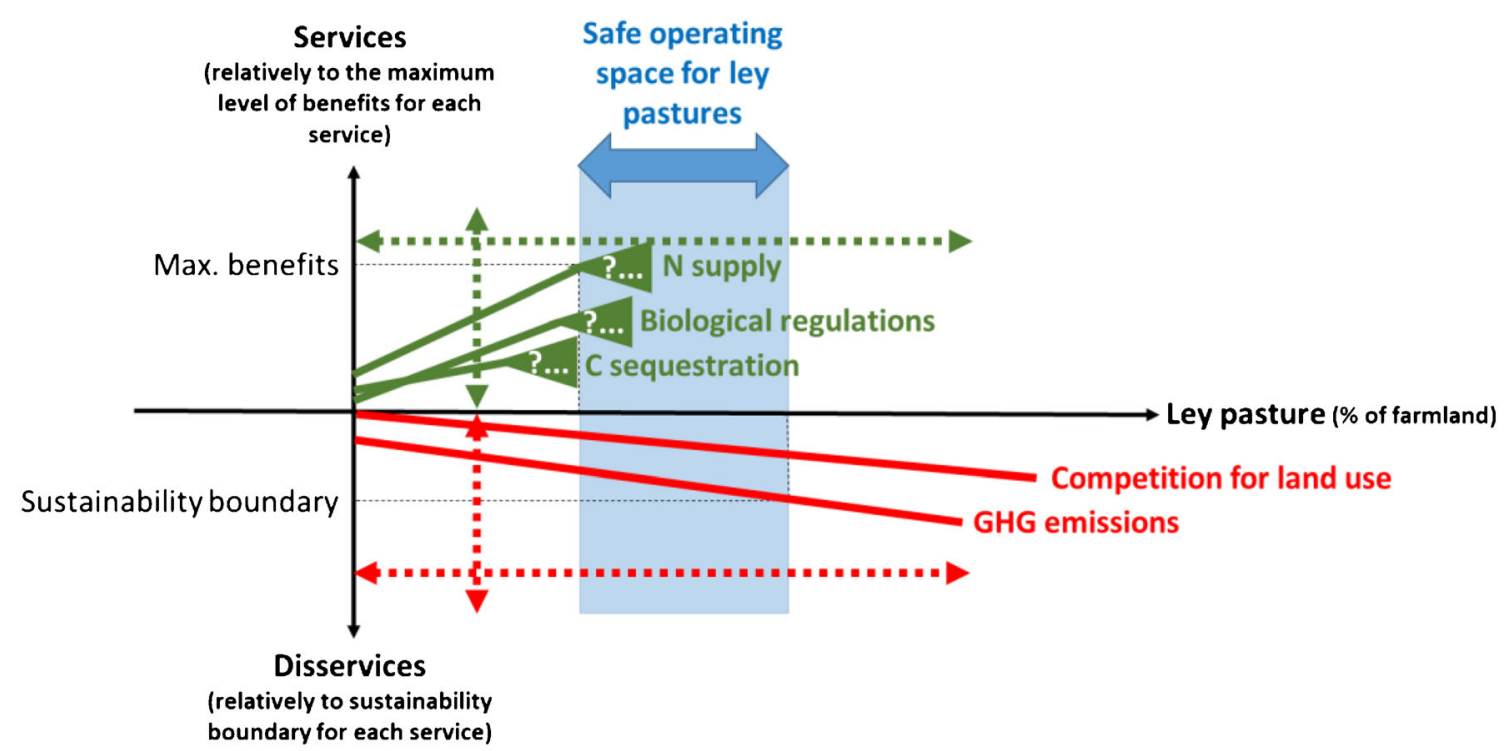

Fig. 5 A framework for defining a safe operating space for ley pastures in cropping systems according to their services and disservices (adapted from Buckwell and Nadeu (2016)). Illustration is provided for 3 services and 2 disservices. The safe operating space for ley pastures in cropping systems is the space located between the maximum level of services observed and the lowest boundary of disservices. Evolution of services and disservices are plotted relatively to their known maximum levels of benefits and sustainability boundaries, respectively. Triangles indicate the uncertainty on the levels of services provided beyond a

ecosystem services bundles they provide, and (iv) identifying acceptable societal compromises at multiple scales and translating them into policy decisions (e.g., regulations, incentives)

\subsection{Breeding varieties for multiservice pastures}

With some exceptions, variety selection and assessment are performed in pure stands. Breeding for mixtures is far more difficult, since it requires either choosing a typical mixture (e.g., alfalfa-cocksfoot/Medicago sativa-Dactylis glomerata, perennial ryegrass-white clover/Lolium perenne-Trifolium repens) or considering a huge number of mixture types (i.e., species, and the number of them). In addition, the one or more companion species chosen could affect how a given new variety performs in a mixture. These practical issues, combined with the major influence of the species themselves (and their varieties) on mixture traits, as mentioned, have strengthened the relevance of breeding in pure stands. Consequently, forage varieties recommended for mixtures are often chosen from those that have been bred and tested in pure stands, for example, in Switzerland (Suter et al. 2008; Frick et al. 2008). However, several experiments have shown that variety or genotype ranking in pure stands differs from that in mixtures (Maamouri et al. 2017; Waldron et al. 2017). This suggests that breeding to improve mixtures is of major importance, as previous studies have concluded (Litrico and Violle 2015). given area and frequency of ley pastures in cropping systems. Dotted vertical arrows indicate the range of the levels of services and disservices provided by ley pastures (along the $Y$-axis), which depend on ley pasture management, particularly the relevance of the spatial and temporal insertion of ley pastures within cropping systems. Dotted horizontal arrows indicate range of the levels of services provided according to the relative area and frequency of ley pastures used to produce livestock products (vs. other uses such as living mulch and green manure). $G H G$ greenhouse gas

In a literature review, selection for yield in pure stands was found to produce predicted yield gains that were $40 \%$ lower, on average, than selection for yield in mixed stands (Annicchiarico et al. 2019). Breeding for mixtures has been conceptualized using the concepts of "general combining ability" (GCA), which refers to the average value of a variety in any mixture, and "specific combining ability" (SCA), which equals the difference between the observed value of a mixture and the average GCA of the components of the mixture (Gallais 1970). Since GCA is usually much higher than SCA (Maamouri et al. 2015), varieties can be selected based on their GCA. In a theoretical study, the genetic progress in a GCA selection program, in which the GCA of the two species are improved in parallel, was higher than that in a "reciprocal combining ability" selection program (Sampoux et al. 2020). Both programs are more efficient than selection in pure stands.

In parallel, a functional approach based on relationships between traits and services could be used. In this approach, the main traits responsible for resource acquisition, complementarity, and competition are identified (Litrico and Violle 2015). This information can be used to define breeding traits in the first step of a selection cycle. For example, for an alfalfa-grass mixture in which the grass has low persistence because the alfalfa (Medicago sativa) shades it, an objective would be to select alfalfa plants with shorter stems and a less erect growth habit than the usual tall and erect ideotype 
(Maamouri et al. 2015). Similarly, white clover (Trifolium sp.) genotypes with long petioles, large leaves, and strong ability to produce stolons can compete better with perennial ryegrass (Lolium perenne) (Davies 2001; Annicchiarico 2003). This kind of selection can be performed easily in a nursery of isolated plants or after progeny testing, in which the most adapted genotypes would enter the GCA selection program mentioned. This approach applies to all traits involved in interactions between plants in mixtures, including light interception, nutrient and water capture, and temporal resource use, and refers to aboveground plant architecture (e.g., height, branching, leaf area, growth habit), rooting depth, root distribution, and phenology.

Evolutionary plant breeding, based on the spontaneous dynamics that drive selection of genotypes in a multispecies pasture over time under a variety of constraints (Litrico and Violle 2015), could be an alternative. Its efficiency relies on the hypothesis that fitness and agronomic value are correlated. The hypothesis may be true if the surviving plants carry traits that confer both competitive ability and yield potential (e.g., plant height) but false if the surviving plants escape stress (e.g., grazing) only because of a prostrate growth habit and low aboveground biomass. Regardless of the breeding method, including the systems-based plant breeding (Lammerts van Bueren et al. 2018) that targets all components of sustainability, breeding programs that aim to improve the varieties used in mixtures should define specific ideotypes and test promising progeny in mixtures before releasing new varieties.

\subsection{Developing a knowledge base on ways to introduce ley pastures into cropping systems}

While traditional ways of sowing and using ley pastures (e.g., haying, grazing) are well-documented in the literature, this is much less the case for emerging ways (e.g., living mulch, cut and carry). Yet, these new forms of introduction of ley pastures into cropping systems could enhance the ecosystem service bundles and decrease the disservices previously mentioned. Improving knowledge about technical and organizational innovations that help introduce ley pastures into cropping systems is needed.

Intercropping is one emerging way to introduce ley pastures into cropping systems. It is a known technical innovation used to limit disservices and enhance ecosystem services in agriculture by taking advantage of functional complementarities among species (Cong et al. 2015). Intercropping takes the form of mixed intercropping (simultaneously growing two or more crops with no, or a limited, distinct arrangement), relay intercropping, and strip intercropping (growing two or more crops simultaneously in strips, allowing for crop interactions and independent cultivation; Brooker et al. 2015). Farmers are broadening this practice to the introduction of ley pastures into low-input cropping systems in at least three ways: sowing ley pasture at the same time as a cash crop (simultaneous intercropping), oversowing ley pasture in an established annual crop as a relay crop, and undersowing an annual crop into the living mulch of ley pasture (Hartwig and Ammon 2002). In the last case, the pasture can remain on the field even after the cash crop is harvested.

Australian farmers have sown pastures at the same time as crops since the 1920s, primarily to offset costs of establishing ley pastures in cropping systems by selling grain (McCormick et al. 2014). The many experiments performed since then have reported that it decreases annual pasture seedset and perennial density. Yet, most farmers in southeastern Australia continue this practice (McCormick et al. 2014), indicating that research may underestimate its benefits. A few studies in Canada and France have addressed simultaneous or relay intercropping of ley pastures in established autumn-seeded winter rye (Secale cereale) and winter wheat (Triticum aestivum) (Edwards 1998), mostly in organic systems (Amossé et al. 2013a, b; Vrignon-Brenas et al. 2016, 2018). There, the short-term ley pasture was considered a cover crop between two cash crops, the services provided being enhanced by relay sowing. Although the practice of cover cropping is developing, relay intercropping of short-duration ley pastures as cover crops remains uncommon. Ley pastures as living mulch for winter cereals (Thorsted et al. 2002; Carof et al. 2007a; Kosinski et al. 2011; Barilli et al. 2017) and sugar beet (Kunz et al. 2016) have also seldom been studied. Most of these studies reported a significant decrease in weed pressure, an occasional increase in $\mathrm{N}$ content in the cash crop but frequently a sharp decrease in crop yield. However, some organic farmers value this practice greatly.

Crop-livestock integration is another way to promote introduction of ley pastures into cropping systems and can occur either at the farm level (Ryschawy et al. 2012) or among farms (Martin et al. 2016). While the former has long been studied and offers well-known opportunities for ley pastures in cropping systems, the latter is a more recent practice that has potential to improve interactions between crops and ley pastures. For example, in specialized crop-production areas experiencing weed and soil-fertility issues, reintroducing transhumant herds managed by independent shepherds to crop farms from mid-autumn to mid-spring before moving to summer mountain pastures is a promising option under development. It may allow crop farmers to reintroduce both shortduration ley pastures as cover crops that the herds can graze as well as perennial ley pastures (e.g., of alfalfa/Medicago sativa) that can reduce weed pressure and increase $\mathrm{N}$ supply for the following crop.

Knowledge of these technical and organizational options remains limited. As highlighted by McCormick et al. (2014) and Brooker et al. (2015), the major research challenges remain understanding complex interactions in these systems 
(e.g., competition between the crop and pasture for light, soil water, and nutrients) and the dependence of these interactions on the context. To this end, experiments need to be performed. Testing cropping systems in realistic on-farm contexts may also provide an effective communication platform to facilitate spread of technical knowledge to commercial farms (Lechenet et al. 2017). Modeling approaches, combined with field experiments, can help gain insight into the complexity and long timeframe of this topic. Tracking on-farm innovations (Casagrande et al. 2017) can help identify promising technical innovations and provide knowledge to other farmers, inspiring them to design their own practices. Tracking farmer practices can provide insight into factors limiting or favoring new techniques.

\subsection{Assessing bundles of ecosystem services provided by ley pastures in cropping systems}

As mentioned, there is much evidence that ley pastures deliver many ecosystem services, but the question of how to bundle these services is difficult to answer since trade-offs may occur. Trade-offs between ecosystem services occur when delivery of one service decreases because that of another service increases. To address this question, we stress the need to consider the processes at the source of ecosystem services, a multiscale approach in space and time, and the influence of ley pasture management.

Rodríguez-Ortega et al. (2014) reviewed studies assessing trade-offs among multiple services at multiple scales (i.e., field, farm, and landscape) in grassland-dominated landscapes. Taking the example of the trade-off between forage production and bird conservation (e.g., Sabatier et al. 2013), they showed that at the field level, it was necessary to adjust grazing intensity over time to ensure conservation of several bird species by minimizing nest trampling and creating optimal grass heights for bird survival without decreasing forage production greatly. At the farm level, hayed and grazed pastures offered contrasting habitats for birds and contrasting feeding resources for livestock. The proportions of hayed/ grazed fields in the farm area thus formed the key mechanism for adjusting the supply of both ecosystem services. At the landscape scale, increasing landscape heterogeneity by changing the spatial arrangement of hayed and grazed pastures increased bird populations without decreasing pasture production. The benefits of heterogeneous land use emerged from a set of interacting suboptimal habitats, in which each type of land use provided some of the resources needed, and species' mobility among land-use types enabled their populations to obtain the resources they needed.

Addressing trade-offs among these two ecosystem services in grassland-dominated landscapes required much effort and a combination of observations and simulation modeling. Thus, few studies consider more than two ecosystem services when analyzing how their interactions support crop production. Garibaldi et al. (2018) analyzed two-way interactions among biotic pest regulation, pollination, and nutrient cycling on crop yield. They found that these three regulating services tended to have complementary or synergistic effects on crop yield and concluded that biodiversity-friendly practices, such as conserving (semi-) natural areas, promoting crop-sequence diversity, and increasing landscape heterogeneity, could alleviate multiple constraints on crop yield. However, their analysis was based on 20 analyses of two-way interactions from 16 studies and did not address the outlets for diversified crops and pastures that may represent lock-ins that impede their reintroduction. This result again shows the complexity of addressing ecosystem service bundles and their location-specific occurrence beyond trade-offs between two given ecosystem services.

Given the classic trade-off between food production and many regulating and cultural services, it is difficult to enhance all ecosystem services simultaneously (Dumont et al. 2018). However, by comparing conventional and organic farming in 12 dimensions of sustainability formulated as services (e.g., increase soil quality, minimize water pollution), Reganold and Wachter (2016) showed that organic farming tends to provide improved bundles. One reason for this may relate to the current place of ley pastures in cropping systems. A recent metaanalysis systematically compared organic and conventional crop sequences at the global scale (Barbieri et al. 2017). It showed that organic farming uses land differently than conventional farming: overall, crop sequences of the former are $15 \%$ longer and result in higher diversity and more even distribution of crop species. These changes are driven by higher area and frequency of ley pastures (e.g., alfalfa/Medicago sativa, clover/Trifolium sp., clover-grass, Italian ryegrass/ Lolium multiflorum), catch crops, and cover crops, mostly to the detriment of cereals. Again, the main limits of these studies are that they rely on partial assessment of one or a few ecosystem services and do not address trade-offs among these services when measured at the same location. A key challenge thus lies in performing more integrated assessment of ecosystem service bundles for several cropping systems including ley pastures in order to compare them to those of cropping systems based only on crops, in a variety of contexts (e.g., soil and climate conditions, farming practices, species sown).

\section{Conclusions}

We have demonstrated that ley pastures in cropping systems can provide a wide range of input services: soil conservation, nutrient provision and recycling, soil water retention, and biological control of pests and weeds. They also provide output services: water purification, climate regulation, habitat provision for conserving associated biodiversity, and forage 
production. Provision of those services holds as long as locally adapted management practices are applied, especially concerning the spatial and temporal insertions of these pastures in cropping systems, the species sown, and pasture use. However, knowledge gaps were clearly identified for some services mainly habitat provision for conserving associated biodiversity and about the impacts of some management options on the level of services supplied especially in the case of emerging ways of introducing ley pastures into cropping systems (e.g., living mulch, "cut and carry"). Those facts indicate that the role and importance of ley pastures in tomorrow's cropping systems and agricultural systems should be reconsidered through an ecologically intensive lens. To this end, interdisciplinary research involving soil scientists, agronomists, geneticists, and ecologists is needed to improve our understanding of the role of ley pastures in cropping systems. These efforts should allow new visions of sustainable cropping systems to be designed that intelligently bring together the new technologies, management practices, and organizations required to integrate ley pastures in tomorrow's cropping systems from the local scale to large scale.

Authors' contribution Conceptualization: GM, JLD, MD, FG, BJ, IL, GL, SM, DM, MVM, SN, VP, FP, FV, ASV, PC, MHJ; Writingoriginal draft preparation: GM, JLD, FG, BJ, IL, GL, SM, DM, MVM, SN, VP, FP, FV, ASV; Writing - review and editing: GM, MD, PC, MHJ; Project administration: GM.

Funding information The authors acknowledge financial support from the INRAE Environment and Agronomy division for the organization of a workshop that served as a starting point for this article.

\section{Compliance with ethical standards}

Conflict of interest The authors declare that they have no conflict of interest.

Open Access This article is licensed under a Creative Commons Attribution 4.0 International License, which permits use, sharing, adaptation, distribution and reproduction in any medium or format, as long as you give appropriate credit to the original author(s) and the source, provide a link to the Creative Commons licence, and indicate if changes were made. The images or other third party material in this article are included in the article's Creative Commons licence, unless indicated otherwise in a credit line to the material. If material is not included in the article's Creative Commons licence and your intended use is not permitted by statutory regulation or exceeds the permitted use, you will need to obtain permission directly from the copyright holder. To view a copy of this licence, visit http://creativecommons.org/licenses/by/4.0/.

\section{References}

AFPF (2017a) Mélanges de semences pour prairies de courte et moyenne durée en France (moins de 3 ans). 8 p. Available at: https://afpf-asso. fr/_objects/tao_medias/file/8-pages-afpf-prairie-courtemoyenneduree-3067.pdf?1546616495.
AFPF (2017b) Mélanges de semences pour prairies de longue durée en France (3 ans en plus). 6 p. Available at: https://afpf-asso.fr/_objects/ tao_medias/file/melanges-prairies-longue-duree-3499.pdf? 1559049664

Aguilar J, Gramig GG, Hendrickson JR, Archer DW, Forcella F, Liebig MA (2015) Crop species diversity changes in the United States: 1978-2012. PLoS One 10:e0136580. https://doi.org/10.1371/ journal.pone. 0136580

Albrecht H (2005) Development of arable weed seedbanks during the 6 years after the change from conventional to organic farming. Weed Res 45:339-350. https://doi.org/10.1111/j.1365-3180.2005.00472.x

Allen VG, Batello C, Berretta EJ et al (2011) An international terminology for grazing lands and grazing animals. Grass Forage Sci 66:228. https://doi.org/10.1111/j.1365-2494.2010.00780.x

Altieri MA (1989) Agroecology: a new research and development paradigm for world agriculture. Agric Ecosyst Environ 27:37-46. https://doi.org/10.1016/0167-8809(89)90070-4

Amossé C, Jeuffroy M-H, David C (2013a) Relay intercropping of legume cover crops in organic winter wheat: effects on performance and resource availability. Field Crop Res 145:78-87. https://doi.org/ 10.1016/J.FCR.2013.02.010

Amossé C, Jeuffroy M-H, Mary B, David C (2013b) Contribution of relay intercropping with legume cover crops on nitrogen dynamics in organic grain systems. Nutr Cycl Agroecosyst 98:1-14. https:// doi.org/10.1007/s10705-013-9591-8

Andersson TN, Milberg P (1996) Weed performance in crop rotations with and without leys and at different nitrogen levels. Ann Appl Biol 128:505-518. https://doi.org/10.1111/j.1744-7348.1996. tb07110.x

Anglade J (2015) Agriculture biologique et qualité des ressources en eau dans le bassin de la Seine. Caractérisation des pratiques et applications territorialisées. Thèse de doctorat de l'Université Pierre et Marie Curie. 272 pp. https://tel.archives-ouvertes.fr/tel-01189101/ document

Anglade J, Billen G, Garnier J (2015) Relationships for estimating N-2 fixation in legumes: incidence for $\mathrm{N}$ balance of legume-based cropping systems in Europe. Ecosphere 6(3):1-24. https://doi.org/ 10.1890/ES14-00353.1

Annicchiarico P (2003) Breeding white clover for increased ability to compete with associated grasses. J Agric Sci 140:255-266. https:// doi.org/10.1017/S0021859603003198

Annicchiarico P, Barrett B, Brummer EC et al (2015) Achievements and challenges in improving temperate perennial forage legumes. Crit Rev Plant Sci 34:327-380. https://doi.org/10.1080/07352689.2014. 898462

Annicchiarico P, Collins RP, De Ron AM et al (2019) Do we need specific breeding for legume-based mixtures? Adv Agron 157:141215. https://doi.org/10.1016/bs.agron.2019.04.001

Annicchiarico P, Pecetti L (2010) Forage and seed yield response of lucerne cultivars to chemically weeded and non-weeded managements and implications for germplasm choice in organic farming. Eur J Agron 33(2):74-80. https://doi.org/10.1016/j.eja.2010.02.006

Ball DM, Collins M, Lacefield GD, Martin NP, Mertens DA, Olson KE, Putnam DH, Undersander DJ, Wolf MW (2001) Understanding forage quality. American Farm Bureau Federation Publication1-01, Park Ridge, IL. Available at: https://fyi.extension.wisc.edu/forage/ files/2017/04/FQ.pdf. Accessed 16 March 2020

Barbieri P, Pellerin S, Nesme T (2017) Comparing crop rotations between organic and conventional farming. Sci Rep-UK 7:13761. https://doi. org/10.1038/s41598-017-14271-6

Barilli E, Jeuffroy MH, Gall J et al (2017) Weed response and crop growth in winter wheat-lucerne intercropping: a comparison of conventional and reduced soil-tillage conditions in northern France. Crop Pasture Sci 68(10-11):1070-1079. https://doi.org/10.1071/ cp16459 
Barkaoui K, Roumet C, Volaire F (2016) Mean root trait more than root trait diversity determines drought resilience in native and cultivated Mediterranean grass mixtures. Agric Ecosyst Environ 231:122-132. https://doi.org/10.1016/j.agee.2016.06.035

Bartel CA, Banik C, Lenssen AW et al (2017) Living mulch for sustainable maize Stover biomass harvest. Crop Sci 57:3273-3290. https:// doi.org/10.2135/cropsci2017.04.0232

Barzman M, Bàrberi P, Birch ANE et al (2015) Eight principles of integrated pest management. Agron Sustain Dev 35:1199-1215. https:// doi.org/10.1007/s13593-015-0327-9

Basset-Mens C, Ledgard S, Boyes M (2009) Eco-efficiency of intensification scenarios for milk production in New Zealand. Ecol Econ 68: 1615-1625. https://doi.org/10.1016/j.ecolecon.2007.11.017

Baumont R, Aufrère J, Niderkorn V et al (2008) La diversité spécifique dans le fourrage: conséquences sur la valeur alimentaire. Fourrages 194:189-206

Baumont R, Dulphy JP, Sauvant D et al (2007) Les tables de valeurs des aliments. In: Alimentation des Bovins, Ovins et Caprins. Quae, Paris, pp 181-275

Benton TG, Vickery JA, Wilson JD (2003) Farmland biodiversity: is habitat heterogeneity the key? Trends Ecol Evol 18:182-188. https://doi.org/10.1016/S0169-5347(03)00011-9

Beuselinck PR, Bouton JH, Lamp WO et al (1994) Improving legume persistence in forage crop systems. J Prod Agric 7:311-322. https:// doi.org/10.2134/jpa1994.0311

Billeter R, Liira J, Bailey D et al (2008) Indicators for biodiversity in agricultural landscapes: a pan-European study. J Appl Ecol 45: $141-150$

Bretagnolle V, Gauffre B, Meiss H, Badenhausser I (2011) The role of grassland areas within arable cropping systems for the conservation of biodiversity at the regional level. In: Grassland productivity and ecosystem services. CAB International, Wallingford, pp 251-260

Brisson N, Gate P, Gouache D et al (2010) Why are wheat yields stagnating in Europe? A comprehensive data analysis for France. Field Crop Res 119:201-212. https://doi.org/10.1016/j.fcr.2010.07.012

Bronick CJ, Lal R (2005) Soil structure and management: a review. Geoderma 124:3-22. https://doi.org/10.1016/j.geoderma.2004.03. 005

Brooker RW, Bennett AE, Cong WF, Daniell TJ, George TS, Hallett PD, Hawes C, Iannetta PP, Jones HG, Karley AJ, Li L, McKenzie B, Pakeman RJ, Paterson E, Schöb C, Shen J, Squire G, Watson CA, Zhang C, Zhang F, Zhang J, White PJ (2015) Improving intercropping: a synthesis of research in agronomy, plant physiology and ecology. New Phytol 206:107-117. https://doi.org/10.1111/nph. 13132

Brown WF, Lai ZQ, Pitman WD (1991) In vitro fibre digestion: associative effects in tropical grass-legume mixtures. Trop Grasslands 25: 297-304

Brunharo CA, Patterson EL, Carrijo DR, de Melo MS, Nicolai M, Gaines TA, Nissen SJ, Christoffoleti PJ (2016) Confirmation and mechanism of glyphosate resistance in tall windmill grass (Chloris elata) from Brazil. Pest Manag Sci 72:1758-1764. https://doi.org/10.1002/ ps. 4205

Brye KR, Norman JM, Bundy LG, Gower ST (2001) Nitrogen and carbon leaching in agroecosystems and their role in denitrification potential. J Environ Qual 30:58-70. https://doi.org/10.2134/jeq2001. $30158 \mathrm{x}$

Buchmann T, Schumacher J, Ebeling A et al (2018) Connecting experimental biodiversity research to real-world grasslands. Perspect Plant Ecol 33:78-88. https://doi.org/10.1016/j.ppees.2018.06.002

Buckwell A, Nadeu E (2016) Nutrient Recovery and Reuse (NRR) in European agriculture. A review of the issues, opportunities, and actions. RISE Foundation, Brussels, Belgium

Burel F, Baudry J, Butet A et al (1998) Comparative biodiversity along a gradient of agricultural landscapes. Acta Oecol 19:47-60. https:// doi.org/10.1016/S1146-609X(98)80007-6
Burel F, Butet A, Delettre YR, de La Peña NM (2004) Differential response of selected taxa to landscape context and agricultural intensification. Landsc Urban Plan 67:195-204

Capitaine M, Pelletier P, Hubert F (2008) Les prairies multispécifiques en France: histoire, réalités et valeurs attendues. Fourrages 194:123136

Carlisle L (2014) Diversity, flexibility, and the resilience effect: lessons from a social-ecological case study of diversified farming in the northern Great Plains, USA. Ecol Soc 19:45. https://doi.org/10. 5751/ES-06736-190345

Carof M, de Tourdonnet S, Saulas P et al (2007a) Undersowing wheat with different living mulches in a no-till system. I. Yield analysis. Agron Sustain Dev 27:347-356. https://doi.org/10.1051/agro: 2007016

Carof M, de Tourdonnet S, Saulas P et al (2007b) Undersowing wheat with different living mulches in a no-till system. II. Competition for light and nitrogen. Agron Sustain Dev 27:357-365. https://doi.org/ 10.1051/agro:2007017

Carrer D, Pique G, Ferlicoq M et al (2018) What is the potential of cropland albedo management in the fight against global warming? A case study based on the use of cover crops. Environ Res Lett 13:4. https://doi.org/10.1088/1748-9326/aab650

Carroll C, Tucker A (2000) Effects of pasture cover on soil erosion and water quality on central Queensland coal mine rehabilitation. Trop Grasslands 34:254-262

Casagrande M, Alletto L, Naudin C, Lenoir A, Siah A, Celette F (2017) Enhancing planned and associated biodiversity in French farming systems. Agron Sustain Dev 37:57-16. https://doi.org/10.1007/ s13593-017-0463-5

Cassman KG (1999) Ecological intensification of cereal production systems: yield potential, soil quality, and precision agriculture. Proc Natl Acad Sci USA 96:5952-5959. https://doi.org/10.1073/pnas. 96.11.5952

Chaplin-Kramer R, O’Rourke ME, Blitzer EJ, Kremen C (2011) A metaanalysis of crop pest and natural enemy response to landscape complexity. Ecol Lett 14:922-932. https://doi.org/10.1111/j.1461-0248. 2011.01642.x

Chauvel B, Guillemin J, Colbach N, Gasquez J (2001) Evaluation of cropping systems for management of herbicide-resistant populations of blackgrass (Alopecurus myosuroides Huds.). Crop Prot 20:127137. https://doi.org/10.1016/S0261-2194(00)00065-X

Clivot H, Mouny JC, Duparque A et al (2019) Modeling soil organic carbon evolution in long-term arable experiments with AMG model. Environ Model Softw 118:99-113. https://doi.org/10.1016/j. envsoft.2019.04.004

Colbach N, Lucas P, Cavelier N (1994) Influence des successions culturales sur les maladies du pied et des racines du blé d'hiver. Agronomie 14:525-540

COMIFER (2011) Calcul de la fertilisation azotée, Guide méthodologique pour l'établissement des prescriptions locales, cultures annuelles et prairies $87 \mathrm{pp}$. Available at https://comifer.asso.fr/ images/publications/brochures/BROCHURE AZOTE 20130705web.pdf

Conant RT, Paustian K, Elliott ET (2001) Grassland management and conversion into grassland: effects on soil carbon. Ecol Appl 11: 343-355. https://doi.org/10.1890/1051-0761(2001)011[0343: GMACIG]2.0.CO;2

Cong WF, Hoffland E, Li L, Six J, Sun JH, Bao XG, Zhang FS, van der Werf W (2015) Intercropping enhances soil carbon and nitrogen. Glob Chang Biol 21:1715-1726. https://doi.org/10.1111/gcb.12738

Constantin J, Mary B, Laurent F et al (2010) Effects of catch crops, no till and reduced nitrogen fertilization on nitrogen leaching and balance in three long-term experiments. Agric Ecosyst Environ 135:268278. https://doi.org/10.1016/j.agee.2009.10.005

Crème A, Rumpel C, Le Roux X et al (2018) Ley grassland under temperate climate had a legacy effect on soil organic matter quantity, 
biogeochemical signature and microbial activities. Soil Biol Biochem 122:203-210. https://doi.org/10.1016/j.soilbio.2018.04. 018

Davies A (2001) Competition between grasses and legumes in established pastures. In: Competition and succession in pastures. CAB International, Wallingford, pp 63-83

Davies MG, Smith KA, Vinten AJA (2001) The mineralisation and fate of nitrogen following ploughing of grass and grass-clover swards. Biol Fertil Soils 33:423-434. https://doi.org/10.1007/s003740100348

Davis AS, Hill JD, Chase CA, Johanns AM, Liebman M (2012) Increasing cropping system diversity balances productivity, profitability and environmental health. PLoS One 7:e47149. https://doi. org/10.1371/journal.pone.0047149

Dear BS, Ewing MA (2008) The search for new pasture plants to achieve more sustainable production systems in southern Australia. Aust J Exp Agric 48:387-396. https://doi.org/10.1071/ea07105

Decau ML, Simon JC, Jacquet A (2003) Fate of urine nitrogen in three soils throughout a grazing season. J Environ Qual 32:1405-1413. https://doi.org/10.2134/jeq2003.1405

Delattre P, Morellet N, Codreanu P et al (2009) Influence of edge effects on common vole population abundance in an agricultural landscape of eastern France. Mammal Res 54:51-60

Diaz-Zorita M, Duarte GA, Grove JH (2002) A review of no-till systems and soil management for sustainable crop production in the subhumid and semiarid Pampas of Argentina. Soil Tillage Res 65:1-18. https://doi.org/10.1016/S0167-1987(01)00274-4

Doisy D, Colbach N, Roger-Estrade J, Médiène S (2014) Weed seed rain interception by grass cover depends on seed traits. Weed Res 54: 593-602. https://doi.org/10.1111/wre.12106

Dollé JB, Klumpp K (2015) Carbon sequestration/release in grassland systems. In: Baseline approaches for the cross-cutting issues of the cattle related product environmental footprint pilots in the context of the pilot phase 2013-2016. DG ENV1, Brussels, pp 20-26

Don A, Scholten T, Schulze ED (2009) Conversion of cropland into grassland: implications for soil organic-carbon stocks in two soils with different texture. J Plant Nutr Soil Sci 172:53-62. https://doi. org/10.1002/jpln.200700158

Ducrocq H, Duru M (1996) Effet de la conduite d'un pâturage tournant sur la digestibilité de l'herbe offerte. Fourrages 145:91-104

Duflot R, Aviron S, Ernoult A et al (2015) Reconsidering the role of 'semi-natural habitat' in agricultural landscape biodiversity: a case study. Ecol Res 30:75-83. https://doi.org/10.1007/s11284-0141211-9

Duflot R, Georges R, Ernoult A et al (2014) Landscape heterogeneity as an ecological filter of species traits. Acta Oecol 56:19-26. https:// doi.org/10.1016/j.actao.2014.01.004

Dumont B, Groot JCJ, Tichit M (2018) Review: make ruminants green again - how can sustainable intensification and agroecology converge for a better future? Animal 12:210-219. https://doi.org/10. 1017/S1751731118001350

Durand JL, Bernard F, Lardy R, Graux AI (2010) Climate change and grassland: the main impacts. In: Climate change, agriculture and forests in France: simulations of the impacts on the main species. The Green Book of the CLIMATOR project (2007-2010). ADEME, Paris, France, pp 181-190

Durand JL, Lemaire G, Gosse G, Chartier M (1989) Analyse de la conversion de l'énergie solaire en matière sèche par un peuplement de luzerne (Medicago sativa L.) soumis à un déficit hydrique. Agronomie 9:599-607

Duru M, Adam M, Cruz P, Martin G, Ansquer P, Ducourtieux C, Jouany C, Theau JP, Viegas J (2009) Modeling above-ground herbage mass for a wide range of grassland community types. Ecol Model 220: 209-225. https://doi.org/10.1016/j.ecolmodel.2008.09.015

Duru M, Cruz P, Theau JP (2008) Un modèle générique de digestibilité des graminées des prairies semées et permanentes pour raisonner les pratiques agricoles. Fourrages 193:79-102
Duru M, Pontes LDAS, Schellberg J, Theau JP, Therond O (2018) Grassland functional diversity and management for enhancing ecosystem services and reducing environmental impacts: a cross-scale analysis. In: Agroecosystem diversity: reconciling contemporary agriculture and environmental quality. Elsevier, Burlington, pp 211230

Dury J, Schaller N, Garcia F et al (2012) Models to support cropping plan and crop rotation decisions. A review. Agron Sustain Dev 32:567580. https://doi.org/10.1007/s13593-011-0037-x

East R, King PD (1977) Effects of botanical composition of pastures on insect pest populations. N Z Entomol 6:273-278. https://doi.org/10. 1080/00779962.1977.9722262

Ecophyto (2017) Note de suivi 2017. Ministère de l'Agriculture, Paris, 36

Edwards L (1998) Comparison of two spring seeding methods to establish forage cover crops in relay with winter cereals. Soil Tillage Res 45:227-235. https://doi.org/10.1016/S0167-1987(97)00065-2

Ergon A, Seddaiu G, Korhonen P et al (2018) How can forage production in Nordic and Mediterranean Europe adapt to the challenges and opportunities arising from climate change? Eur J Agron 92:97106. https://doi.org/10.1016/j.eja.2017.09.016

FAO (2019) FAOSTAT. Available at: http://www.fao.org/faostat/en/\# home. Accessed 16 March 2020

Faverjon L, Escobar-Gutiérrez A, Litrico I, Julier B, Louarn G (2019) A generic individual-based model can predict yield, nitrogen content, and species abundance in experimental grassland communities. J Exp Bot 70:2491-2504. https://doi.org/10.1093/jxb/ery323

Finckh M, Gacek E, Goyeau H et al (2000) Cereal variety and species mixtures in practice, with emphasis on disease resistance. Agronomie 20:813-837. https://doi.org/10.1051/agro:2000177

Finn JA, Kirwan L, Connolly J et al (2013) Ecosystem function enhanced by combining four functional types of plant species in intensively managed grassland mixtures: a 3-year continental-scale field experiment. J Appl Ecol 50:365-375. https://doi.org/10.1111/1365-2664. 12041

Finney DM, Murrell EG, White CM et al (2017) Ecosystem services and disservices are bundled in simple and diverse cover cropping systems. Agr Environ Lett 2:170033. https://doi.org/10.2134/ael2017. 09.0033

Finney DM, White CM, Kaye JP (2016) Biomass production and carbon/ nitrogen ratio influence ecosystem services from cover crop mixtures. Agron J 108:39. https://doi.org/10.2134/agronj15.0182

Fischer C, Roscher C, Jensen B et al (2014) How do earthworms, soil texture and plant composition affect infiltration along an experimental plant diversity gradient in grassland? PLoS One 9:98987. https:// doi.org/10.1371/journal.pone.0098987

Fisk JW, Hesterman OB, Shrestha A et al (2001) Weed suppression by annual legume cover crops in no-tillage corn. Agron J 93:319. https://doi.org/10.2134/agronj2001.932319x

Franzluebbers A (2008) Linking soil and water quality in conservation agricultural systems. J Integr Biosci 6:15-29

Franzluebbers AJ, Gastal F (2018) Building agricultural resilience with conservation pasture-crop rotations. In: Agroecosystem diversity: reconciling contemporary agriculture and environmental quality. Elsevier, Burlington, pp 109-121

Franzluebbers AJ, Sawchik J, Taboada MA (2014) Agronomic and environmental impacts of pasture-crop rotations in temperate North and South America. Agric Ecosyst Environ 190:18-26. https://doi.org/ 10.1016/j.agee.2013.09.017

Franzluebbers AJ, Stuedemann JA, Franklin DH (2012) Water infiltration and surface-soil structural properties as influenced by animal traffic in the Southern Piedmont USA. Renew Agric Food Syst 27:256265. https://doi.org/10.1017/s1742170511000378

Franzluebbers AJ, Stuedemann JA, Schomberg HH, Wilkinson SR (2000) Soil organic C and N pools under long-term pasture 
management in the southern Piedmont USA. Soil Biol Biochem 32: 469-478. https://doi.org/10.1016/S0038-0717(99)00176-5

Franzluebbers AJ, Stuedemann JA (2008) Early response of soil organic fractions to tillage and integrated crop-livestock production. Soil Sci Soc Am J 72:613-625. https://doi.org/10.2136/sssaj2007.0121

Frick R, Mosimann E, Suter D (2008) Expérience sur la mise en ouvre de prairies multispécifiques. Histoire et rôles des mélanges semés en Suisse. Fourrages 194:221-231

Fu B, Liu Y, Lü Y et al (2011) Assessing the soil erosion control service of ecosystems change in the Loess Plateau of China. Ecol Complex 8: 284-293. https://doi.org/10.1016/j.ecocom.2011.07.003

Fullen MA (1998) Effects of grass ley set-aside on runoff, erosion and organic matter levels in sandy soils in East Shropshire, UK. Soil Tillage Res 46:41-49. https://doi.org/10.1016/S0167-1987(98) 80106-2

Gallais A (1970) Modèle pour l'analyse des relations d'associations binaires. Biométrie-Praximétrie 11:51-80

Gardiner T, Gardiner M, Hill J (2005) The effect of pasture improvement and burning on Orthoptera populations of Culm grasslands in northwest Devon, UK. J Orthop Res 14:153-160

Garibaldi LA, Andersson GKS, Requier F et al (2018) Complementarity and synergisms among ecosystem services supporting crop yield. Glob Food Secur 17:38-47. https://doi.org/10.1016/j.gfs.2018.03. 006

Gastal F, Dawson LA, Thornton B (2010) Responses of plant traits of four grasses from contrasting habitats to defoliation and $\mathrm{N}$ supply. Nutr Cycl Agroecosyst 88:245-258. https://doi.org/10.1007/s10705010-9352-x

Gastal F, Lemaire G, Durand JL, Louarn G (2015) Quantifying crop responses to nitrogen and avenues to improve nitrogen use efficiency. In: Crop physiology - applications for genetic improvement and agronomy. Elsevier, Burlington, pp 161-206

Gastal F, Durand JL (2000) Effects of nitrogen and water supply on N and $\mathrm{C}$ fluxes and partitioning in defoliated swards. In: Grassland ecophysiology and grazing ecology. CAB International, Wallingford, pp 15-39

Gaudio N, Escobar-Gutierrez AJ, Casadebaig P et al (2019) Current knowledge and future research opportunities for modeling annual crop mixtures. A review. Agron Sustain Dev 39:20-20. https://doi. org/10.1007/s13593-019-0562-6

Gosse G, Lemaire G, Chartier M, Balfourier F (1988) Structure of a lucerne population (Medicago sativa L.) and dynamics of stem competition for light during regrowth. J Appl Ecol 25:609-617. https:// doi.org/10.2307/2403848

Gosse G, Varlet-Grancher C, Bonhomme R et al (1986) Production maximale de matière sèche et rayonnement solaire intercepté par un couvert végétal. Agronomie 6:47-56

Goutiers V, Charron MH, Deo M, Hazard L (2016) Capflor (R): a tool for designing species mixtures and thus creating diversified grasslands. Fourrages 228:243-252

Graux AI, Resmond R, Casellas E et al (2020) High-resolution assessment of French grassland dry matter and nitrogen yields. Eur J Agron 112:125952. https://doi.org/10.1016/j.eja.2019.125952

Gross K, Cardinale BJ, Fox JW, Gonzalez A, Loreau M, Polley HW, Reich PB, van Ruijven J (2014) Species richness and the temporal stability of biomass production: a new analysis of recent biodiversity experiments. Am Nat 183:1-12. https://doi.org/10.1086/673915

Guo LB, Gifford RM (2002) Soil carbon stocks and land use change: a meta analysis. Glob Chang Biol 8:345-360. https://doi.org/10.1046/ j.1354-1013.2002.00486.x

Gyssels G, Poesen J, Bochet E, Li Y (2005) Impact of plant roots on the resistance of soils to erosion by water: a review. Prog Phys Geogr 29:189-217. https://doi.org/10.1191/0309133305pp443ra

Habel JC, Ulrich W, Biburger N et al (2019) Agricultural intensification drives butterfly decline. Insect Conserv Diver. https://doi.org/10. 1111/icad.12343
Hallmann CA, Sorg M, Jongejans E et al (2017) More than 75 percent decline over 27 years in total flying insect biomass in protected areas. PLoS One 12(10):e0185809. https://doi.org/10.1371/journal. pone.0185809

Hartwig NL, Ammon HU (2002) Cover crops and living mulches. Weed Sci 50:688-699. https://doi.org/10.1614/0043-1745(2002) 050[0688:aiacca]2.0.co;2

Hayes RC, Li GD, Norton MR, Culvenor RA (2018) Effects of contrasting seasonal growth patterns on composition and persistence of mixed grass-legume pastures over 5years in a semi-arid Australian cropping environment. J Agron Crop Sci 204:228-242. https://doi. org/10.1111/jac. 12258

Haynes RJ (1999) Labile organic matter fractions and aggregate stability under short-term, grass-based leys. Soil Biol Biochem 31:18211830. https://doi.org/10.1016/S0038-0717(99)00102-9

Hector A, Hooper R (2002) Ecology - Darwin and the first ecological experiment. Science 295:639-640. https://doi.org/10.1126/science. 1064815

Heggenstaller AH, Menalled FD, Liebman M, Westerman PR (2006) Seasonal patterns in post-dispersal seed predation of Abutilon theophrasti and Setaria faberi in three cropping systems. J Appl Ecol 43:999-1010. https://doi.org/10.1111/j.1365-2664.2006. 01198.x

Helgadottir A, Suter M, Gylfadottir TO et al (2018) Grass-legume mixtures sustain strong yield advantage over monocultures under cool maritime growing conditions over a period of 5 years. Ann Bot 122: 337-348. https://doi.org/10.1093/aob/mcy074

Hendrickx F, Maelfait JP, Van Wingerden W et al (2007) How landscape structure, land-use intensity and habitat diversity affect components of total arthropod diversity in agricultural landscapes. J Appl Ecol 44:340-351. https://doi.org/10.1111/j.1365-2664.2006.01270.x

Hermann A, Brunner N, Hann P, Wrbka T, Kromp B (2013) Correlations between wireworm damages in potato fields and landscape structure at different scales. J Pest Sci 86:41-51. https://doi.org/10.1007/ s10340-012-0444-Z

Hiddink GA, Termorshuizen AJ, van Bruggen AH (2010) Mixed cropping and suppression of soilborne diseases. In: Genetic engineering, biofertilisation, soil quality and organic farming. Springer, Dordrecht, pp 119-146

Hiltbrunner J, Scherrer C, Streit B et al (2008) Long-term weed community dynamics in Swiss organic and integrated farming systems. Weed Res 48:360-369. https://doi.org/10.1111/j.1365-3180.2008. 00639.x

Humphreys MW, Yadav RS, Cairns AJ, Turner LB, Humphreys J, Skøt L (2006) A changing climate for grassland research. New Phytol 169: 9-26. https://doi.org/10.1111/j.1469-8137.2005.01549.x

Huyghe C, De Vliegher A, Van Gils B, Peeters A (2014) Grasslands and herbivore production in Europe and effects of common policies. Quae, Paris

INRA-CIRAD-AFZ (2018) Feed tables - composition and nutritive values of feeds for cattle, sheep, goats, pigs, poultry, rabbits, horses and salmonids. Available at: https://www.feedtables.com/. Accessed 16 March 2020

Isbell F, Calcagno V, Hector A, Connolly J, Harpole WS, Reich PB, Scherer-Lorenzen M, Schmid B, Tilman D, van Ruijven J, Weigelt A, Wilsey BJ, Zavaleta ES, Loreau M (2011) High plant diversity is needed to maintain ecosystem services. Nature 477:199-202. https://doi.org/10.1038/nature10282

Johnston AE, Poulton PR, Coleman K, Macdonald AJ, White RP (2017) Changes in soil organic matter over 70 years in continuous arable and ley-arable rotations on a sandy loam soil in England. Eur J Soil Sci 68:305-316. https://doi.org/10.1111/ejss.12415

Jones MB, Lazenby A (1988) The grass crop. The physiological basis of production. Chapman \& Hall, London 
Julier B, Gastal F, Louarn G et al (2017) Lucerne (alfalfa) in European cropping systems. In: Legumes in cropping systems. CAB International, Wallingford, pp 168-192

Jun F, Mingan S, QanJiu W et al (2010) Toward sustainable soil and water resources use in China's highly erodible semi-arid loess plateau. Geoderma 155:93-100. https://doi.org/10.1016/j.geoderma.2009. 11.027

Khanh T, Chung M, Xuan T, Tawata S (2005) The exploitation of crop allelopathy in sustainable agricultural production. J Agron Crop Sci 191:172-184. https://doi.org/10.1111/j.1439-037X.2005.00172.x

Kim K-H, Kabir E, Jahan SA (2017) Exposure to pesticides and the associated human health effects. Sci Total Environ 575:525-535. https://doi.org/10.1016/J.SCITOTENV.2016.09.009

Kindler R, Siemens J, Kaiser K et al (2011) Dissolved carbon leaching from soil is a crucial component of the net ecosystem carbon balance. Glob Chang Biol 17:1167-1185. https://doi.org/10.1111/j. 1365-2486.2010.02282.x

Kirwan L, Lüscher A, Sebastià MT et al (2007) Evenness drives consistent diversity effects in intensive grassland systems across 28 European sites. J Ecol 95:530-539. https://doi.org/10.1111/j.13652745.2007.01225.x

Klumpp K, Fornara D (2018) The carbon sequestration of grassland soils - climate change and mitigation strategies. Grassland Sci Eur 23: 509-519

Kosinski SM, King JR, Harker KN et al (2011) Barley and triticale underseeded with a kura clover living mulch: effects on weed pressure, disease incidence, silage yield, and forage quality. Can J Plant Sci 91(4):677-687. https://doi.org/10.4141/cjps10138

Kremen C, Iles A, Bacon C (2012) Diversified farming systems: an agroecological, systems-based alternative to modern industrial agriculture. Ecol Soc 17:44. https://doi.org/10.5751/ES-05103-170444

Kremen C, Miles A (2012) Ecosystem services in biologically diversified versus conventional farming systems: benefits, externalities, and trade-offs. Ecol Soc 17:40. https://doi.org/10.5751/ES-05035170440

Kunrath TR, de Berranger C, Charrier X et al (2015) How much do sodbased rotations reduce nitrate leaching in a cereal cropping system? Agric Water Manage 150:46-56. https://doi.org/10.1016/j.agwat. 2014.11.015

Kunz C, Sturm DJ, Peteinatos GG, Gerhards R (2016) Weed suppression of living mulch in sugar beets. Gesunde Pflanzen 68:145-154. https://doi.org/10.1007/s10343-016-0370-8

Lal R (2008) Soil carbon stocks under present and future climate with specific reference to European ecoregions. Nutr Cycl Agroecosyst 81:113-127. https://doi.org/10.1007/s10705-007-9147-x

Lamande M, Hallaire V, Curmi P et al (2003) Changes of pore morphology, infiltration and earthworm community in a loamy soil under different agricultural managements. Catena 54:637-649. https://doi. org/10.1016/S0341-8162(03)00114-0

Lamande M, Eriksen J, Krogh PH, Jacobsen OH (2017) Water flow in soil from organic dairy rotations. J Agric Sci 155:1113-1123. https:// doi.org/10.1017/s0021859617000089

Lammerts van Bueren ET, Struik PC, van Eekeren N, Nuijten E (2018) Towards resilience through systems-based plant breeding. A review. Agron Sustain Dev 38:42. https://doi.org/10.1007/s13593-018-0522

Lange M, Eisenhauer N, Sierra CA et al (2015) Plant diversity increases soil microbial activity and soil carbon storage. Nat Commun 6:6707. https://doi.org/10.1038/ncomms770

Lechenet M (2017) Peut-on concilier un faible usage de pesticides, une bonne performance économique et environnementale ? Analyse d'un réseau national de fermes de démonstration Ecophyto. Ph.D. thesis, Université de Bourgogne Franche-Comté

Lechenet M, Dessaint F, Py G, Makowski D, Munier-Jolain N (2017) Reducing pesticide use while preserving crop productivity and profitability on arable farms. Nat Plants 3:17008. https://doi.org/10. 1038/nplants.2017.8
Lechenet M, Makowski D, Py G, Munier-Jolain N (2016) Profiling farming management strategies with contrasting pesticide use in France. Agric Syst 149:40-53. https://doi.org/10.1016/j.agsy.2016.08.005

Ledgard S, Schils R, Eriksen J, Luo J (2009) Environmental impacts of grazed clover/grass pastures. Irish J Agric Food Res 48:209-226

Lee J (1988) Forages. Livest Prod Sci 19:13-46. https://doi.org/10.1016/ 0301-6226(88)90085-1

Lemaire G, Gastal F, Franzluebbers A, Chabbi A (2015) Grasslandcropping rotations: an avenue for agricultural diversification to reconcile high production with environmental quality. Environ Manag 56:1065-1077. https://doi.org/10.1007/s00267-015-0561-6

Lemaire G, Durand JL, Lila M (1989) Effet de la sécheresse sur la digestibilité in vitro, la teneur en ADF et la teneur en azote de la luzerne (Medicago sativa L.). Agronomie 9:841-848

Lemaire G, Hodgson J, Moraes AD et al (2000) Grassland ecophysiology and grazing ecology. $\mathrm{CAB}$ International, Wallingford

Leterme P, Barré C, Vertès F (2003) The fate of $15 \mathrm{~N}$ from dairy cow urine under pasture receiving different rates of $\mathrm{N}$ fertiliser. Agronomie 23: 609-616

Liebman M, Dyck E (1993) Crop rotation and intercropping strategies for weed management. Ecol Appl 3:92-122. https://doi.org/10.2307/ 1941795

Liebman M, Gallandt E (1997) Many little hammers: ecological management of crop-weed interactions. In: Ecology in agriculture. Academic, San Diego, pp 291-343

Litrico I, Violle C (2015) Diversity in plant breeding a new conceptual framework. Trends Plant Sci 20:604-613. https://doi.org/10.1016/j. tplants.2015.07.007

Loiseau P, Chevallier T (2002) Changement d'usage des terres: passage cultures-prairies. In: Stocker du carbone dans les sols agricoles de France? INRA, Paris, pp 168-171

Lopez-Arredondo DL, Leyva-Gonzalez MA, Gonzalez-Morales SI et al (2014) Phosphate nutrition: improving low-phosphate tolerance in crops. Annu Rev Plant Biol 65:95-123. https://doi.org/10.1146/ annurev-arplant-050213-035949

Louarn G, Barillot R, Combes D, Escobar-Gutiérrez A (2018) Assessing key traits to promote overyielding in mixtures of legumes and nonlegumes: a case study using the Virtual Grassland model. Proceedings of the IEEE 6th International Symposium on Plant Growth Modeling, Simulation, Visualization and Applications (PMA). Hefei, China, 04-08 Nov 2018, 18397218. https://doi.org/ 10.20071109/PMA.2018.8611602

Lu ZX, Zhu PY, Gurr GM, Zheng XS, Read DM, Heong KL, Yang YJ, Xu HX (2014) Mechanisms for flowering plants to benefit arthropod natural enemies of insect pests: prospects for enhanced use in agriculture. Insect Sci 21:1-12. https://doi.org/10.1111/1744-7917. 12000

Lüscher A, Huguenin-Elie O, Suter M et al (2017) From research to practice: grass-legume mixtures as a pillar for sustainable intensification. Asp Appl Biol 136:103-106

Maamouri A, Louarn G, Beguier V, Julier B (2017) Performance of lucerne genotypes for biomass production and nitrogen content differs in monoculture and in mixture with grasses and is partly predicted from traits recorded on isolated plants. Crop Past Sci 68:942 951. https://doi.org/10.1071/cp17052

Maamouri A, Louarn G, Gastal F et al (2015) Effects of lucerne genotype on morphology, biomass production and nitrogen content of lucerne and tall fescue in mixed pastures. Crop Past Sci 66:192-204. https:// doi.org/10.1071/cp14164

Marshall EJP, Brown VK, Boatman ND et al (2003) The role of weeds in supporting biological diversity within crop fields. Weed Res 43:7789. https://doi.org/10.1046/j.1365-3180.2003.00326.x

Martin G, Moraine M, Ryschawy J, Magne MA, Asai M, Sarthou JP, Duru M, Therond O (2016) Crop-livestock integration beyond the farm level: a review of prospects and issues. Agron Sustain Dev 36: 53-21. https://doi.org/10.1007/s13593-016-0390-x 
McCormick JI, Hayes RC, Li GD, Norton MR (2014) A review of pasture establishment by undersowing with special reference to the mixed farming zone of south-eastern Australia. Crop Past Sci 65:956. https://doi.org/10.1071/CP14049

Meilhac J, Durand JL, Béguier V, Litrico I (2019) Increasing the benefits of species diversity in multispecies temporary grasslands by increasing within-species diversity. Ann Bot. https://doi.org/10.1093/aob/ $\operatorname{mcy} 227$

Meiss H, Munier-Jolain N, Henriot F, Caneill J (2008) Effects of biomass, age and functional traits on regrowth of arable weeds after cutting. J Plant Dis Protect 21:493-499

Meiss H, Le Lagadec L, Munier-Jolain N et al (2010a) Weed seed predation increases with vegetation cover in perennial forage crops. Agric Ecosyst Environ 138:10-16. https://doi.org/10.1016/j.agee.2010.03. 009

Meiss H, Médiène S, Waldhardt R et al (2010b) Perennial lucerne affects weed community trajectories in grain crop rotations. Weed Res 50: 331-340. https://doi.org/10.1111/j.1365-3180.2010.00784.x

Meiss H, Médiène S, Waldhardt R, Caneill J, Munier-Jolain N (2010c) Contrasting weed species composition in perennial alfalfas and six annual crops: implications for integrated weed management. Agron Sustain Dev 30:657-666. https://doi.org/10.1051/agro/2009043

Meng Q, Chen X, Lobell DB, Cui Z, Zhang Y, Yang H, Zhang F (2016) Growing sensitivity of maize to water scarcity under climate change. Sci Rep 6:19605-19607. https://doi.org/10.1038/srep19605

Meyer JR, Campbell CL, Moser TJ et al (1992) Indicators of the ecological status of agroecosystems. In: Ecological indicators. Springer, Boston, USA, pp 629-658

Miglécz T, Valkó O, Török P et al (2015) Establishment of three cover crop mixtures in vineyards. Sci Hortic (Amsterdam) 197:117-123. https://doi.org/10.1016/J.SCIENTA.2015.09.017

Mignolet C, Schott C, Benoit M, Meynard J (2012) Transformations des systèmes de production et des systèmes de culture du bassin de la Seine depuis les années 1970 : une spécialisation des territoires aux conséquences environnementales majeures. Innov Agron 22:1-16

Minasny B, Malone BP, McBratney AB et al (2017) Soil carbon 4 per mille. Geoderma 292:59-86. https://doi.org/10.1016/j.geoderma. 2017.01.002

Monard C, Martin-Laurent F, Vecchiato C et al (2008) Combined effect of bioaugmentation and bioturbation on atrazine degradation in soil. Soil Biol Biochem 40:2253-2259. https://doi.org/10.1016/j.soilbio. 2008.04.022

Moore FC, Lobell DB (2015) The fingerprint of climate trends on European crop yields. Proc Natl Acad Sci U S A 112:2670-2675. https://doi.org/10.1073/pnas.1409606112

Muller A, Schader C, El-Hage Scialabba N et al (2017) Strategies for feeding the world more sustainably with organic agriculture. Nat Commun 8:1290. https://doi.org/10.1038/s41467-017-01410-w

Necpalova N, Li D, Lanigan G et al (2014) Changes in soil organic carbon in a clay loam soil following ploughing and reseeding of permanent grassland under temperate moist climatic conditions. Grass Forage Sci 69:611-624. https://doi.org/10.1111/gfs.12080

Nguyen TTH, Corson MS, Doreau M, Eugène M, Werf HMG (2013a) Consequential LCA of switching from maize silage-based to grassbased dairy systems. Int J Life Cycle Assess 18:1470-1484. https:// doi.org/10.1007/s11367-013-0605-1

Nguyen TTH, Doreau M, Corson MS, Eugène M, Delaby L, Chesneau G, Gallard Y, van der Werf H (2013b) Effect of dairy production system, breed and co-product handling methods on environmental impacts at farm level. J Environ Manag 120:127-137. https://doi.org/ 10.1016/j.jenvman.2013.01.028

Norris RF, Ayres D (1991) Cutting interval and irrigation timing in alfalfa: yellow foxtail invasion and economic analysis. Agron J 83:552558. https://doi.org/10.2134/agronj1991.00021962008300030007x

Nyfeler D, Huguenin-Elie O, Suter M et al (2011) Grass-legume mixtures can yield more nitrogen than legume pure stands due to mutual stimulation of nitrogen uptake from symbiotic and non-symbiotic sources. Agric Ecosyst Environ 140:155-163. https://doi.org/10. 1016/j.agee.2010.11.022

Nyfeler D, Huguenin-Elie O, Suter M et al (2009) Strong mixture effects among four species in fertilized agricultural grassland led to persistent and consistent transgressive overyielding. J Appl Ecol 46:683691. https://doi.org/10.1111/j.1365-2664.2009.01653.x

Obour PB, Jensen JL, Lamande M et al (2018) Soil organic matter widens the range of water contents for tillage. Soil Tillage Res 182:57-65. https://doi.org/10.1016/j.still.2018.05.001

Ominski P, Entz M, Kenkel N (1999) Weed suppression by Medicago sativa in subsequent cereal crops: a comparative survey. Weed Sci 47:282-290. https://doi.org/10.1017/S0043174500091785

Panagosa P, Borrelli P, Meusburgerb K et al (2015) Estimating the soil erosion cover-management factor at the European scale. Land Use Policy 48:38-50. https://doi.org/10.1016/j.landusepol.2015.05.021

Parker WE, Howard JJ (2001) The biology and management of wireworms (Agriotes spp.) on potato with particular reference to the UK. Agric Forest Entomol 3:85-98. https://doi.org/10.1046/j. 1461-9563.2001.00094.x

Parkin TB (1993) Spatial variability of microbial processes in soil - a review. J Environ Qual 22:409-417. https://doi.org/10.2134/ jeq1993.00472425002200030004x

Pembleton LW, Wang J, Spangenberg GC et al (2016) Low-cost automated biochemical phenotyping for optimised nutrient quality components in ryegrass breeding. Crop Pasture Sci 67:888-896. https:// doi.org/10.1071/cp16102

Pellerin S, Bamière L, Angers D et al (2017) Identifying cost-competitive greenhouse gas mitigation potential of French agriculture. Environ Sci Pol 77:130-139. https://doi.org/10.1016/j.envsci.2017.08.003

Pellerin S, Bamière L, Launay C et al (2019) Stocker du carbone dans les sols français, Quel potentiel au regard de l'objectif 4 pour 1000 et à quel coût ? Synthèse du rapport d'étude. INRA, Paris, $114 \mathrm{p}$

Petit S, Cordeau S, Chauvel B, Bohan D, Guillemin JP, Steinberg C (2018) Biodiversity-based options for arable weed management. A review. Agron Sustain Dev 38:48-21. https://doi.org/10.1007/ s13593-018-0525-3

Peyraud J-L, Taboada M, Delaby L (2014) Integrated crop and livestock systems in Western Europe and South America: a review. Eur J Agron 57:31-42. https://doi.org/10.1016/j.eja.2014.02.005

Pietola L, Horn R, Yli-Halla M (2005) Effects of trampling by cattle on the hydraulic and mechanical properties of soil. Soil Tillage Res 82: 99-108. https://doi.org/10.1016/j.still.2004.08.004

Poeplau C, Don A, Vesterdal L et al (2011) Temporal dynamics of soil organic carbon after land-use change in the temperate zone - carbon response functions as a model approach. Glob Chang Biol 17:24152427. https://doi.org/10.1111/j.1365-2486.2011.02408.x

Poirier M, Durand JL, Volaire F (2012) Persistence and production of perennial grasses under water deficits and extreme temperatures: importance of intraspecific vs. interspecific variability. Glob Chang Biol 18:3632-3646. https://doi.org/10.1111/j.1365-2486. 2012.02800.x

Ponisio LC, M'Gonigle LK, Mace KC et al (2015) Diversification practices reduce organic to conventional yield gap. Proc R Soc Lond B Biol Sci 282:20141396. https://doi.org/10.1098/rspb.2014.1396

Porqueddu C, Ates S, Louhaichi M et al (2016) Grasslands in 'Old World' and 'New World' Mediterranean-climate zones: past trends, current status and future research priorities. Grass Forage Sci 71(1): 1-35. https://doi.org/10.1111/gfs.12212

Poux X, Aubert PM (2018) An agroecological Europe in 2050: multifunctional agriculture for healthy eating. Findings from the Ten Years For Agroecology (TYFA) modelling exercise. Available at: https://www.iddri.org/sites/default/files/PDF/Publications/ Catalogue\%20Iddri/Etude/201809-ST0918EN-tyfa.pdf. Accessed 16 March 2020 
Pretty J, Bharucha ZP (2014) Sustainable intensification in agricultural systems. Ann Bot 114:1571-1596. https://doi.org/10.1093/aob/ mcu205

Prieto I, Violle C, Barre P, Durand JL, Ghesquiere M, Litrico I (2015) Complementary effects of species and genetic diversity on productivity and stability of sown grasslands. Nat Plants 1:15033. https:// doi.org/10.1038/nplants.2015.33

Puerta VL, Pereira EIP, Wittwer R et al (2018) Improvement of soil structure through organic crop management, conservation tillage and grass-clover ley. Soil Tillage Res 180:1-9. https://doi.org/10. 1016/j.still.2018.02.007

Rasmussen J, Soegaard K, Pirhofer-Walzl K, Eriksen J (2012) N2fixation and residual $\mathrm{N}$ effect of four legume species and four companion grass species. Eur J Agron 36:66-74. https://doi.org/10. 1016/j.eja.2011.09.003

Raudsepp-Hearne C, Peterson GD, Bennett EM (2010) Ecosystem service bundles for analyzing tradeoffs in diverse landscapes. Proc Natl Acad Sci U S A 107:5242-5247. https://doi.org/10.1073/pnas. 0907284107

Ray DK, Ramankutty N, Mueller ND et al (2012) Recent patterns of crop yield growth and stagnation. Nat Commun 3:1293. https://doi.org/ 10.1038/ncomms 2296

Reckling M, Hecker J-M, Bergkvist G et al (2016) A cropping system assessment framework - evaluating effects of introducing legumes into crop rotations. Eur J Agron 76:186-197. https://doi.org/10. 1016/j.eja.2015.11.005

Recous S, Lashermes G, Bertrand I (2017) Couplages et contrôles des cycles du carbone et de l'azote par les communautés microbiennes dans les sols cultivés. In: Les sols et la vie souterraine: Des enjeux majeurs en agroécologie. Quae, Paris, pp 43-63

Reganold JP, Wachter JM (2016) Organic agriculture in the 21st century. Nat Plants 2:15221. https://doi.org/10.1038/NPLANTS.2015.221

Rockström J, Steffen W, Noone K et al (2009) A safe operating space for humanity. Nature 461:472-475. https://doi.org/10.1038/461472a

Rodríguez-Ortega T, Oteros-Rozas E, Ripoll-Bosch R et al (2014) Applying the ecosystem services framework to pasture-based livestock farming systems in Europe. Animal 8:1361-1372. https://doi. org/10.1017/S1751731114000421

Röös E, Bajželj B, Smith P et al (2017) Greedy or needy? Land use and climate impacts of food in 2050 under different livestock futures. Glob Environ Chang 47:1-12. https://doi.org/10.1016/J. GLOENVCHA.2017.09.001

Rösch C, Skarka J, Raab K, Stelzer V (2009) Energy production from grassland - assessing the sustainability of different process chains under German conditions. Biomass Bioenergy 33:689-700. https:// doi.org/10.1016/j.biombioe.2008.10.008

Roscher C, Schumacher J, Baade J et al (2004) The role of biodiversity for element cycling and trophic interactions: an experimental approach in a grassland community. Basic Appl Ecol 5:107-121. https://doi.org/10.1078/1439-1791-00216

Rumpel C, Chabbi A (2018) Plante soil interactions control CNP coupling and decoupling processes in agroecosystems with perennial vegetation. In: Agroecosystem diversity: reconciling contemporary agriculture and environmental quality. Elsevier, Burlington, pp 3-13

Ryschawy J, Choisis N, Choisis JP et al (2012) Mixed crop-livestock systems: an economic and environmental-friendly way of farming? Animal 6:1722-1730. https://doi.org/10.1017/S1751731112000675

Sabatier R, Meyer K, Wiegand K, Clough Y (2013) Non-linear effects of pesticide application on biodiversity-driven ecosystem services and disservices in a cacao agroecosystem: a modeling study. Basic Appl Ecol 14:93-186. https://doi.org/10.1016/j.baae.2012.12.006

Saini RK, Malone J, Preston C, Gill G (2015) Target enzyme-based resistance to Clethodim in Lolium rigidum populations in Australia. Weed Sci 63:946-953. https://doi.org/10.1614/WS-D-14-00176.1
Salou T, Le Mouël C, van der Werf H (2017) Environmental impacts of dairy system intensification: the functional unit matters! J Clean Prod 140:445-454. https://doi.org/10.1016/j.jclepro.2016.05.019

Sampoux JP, Giraud H, Litrico I (2020) Which recurrent selection scheme to improve mixtures of crop species? Theoretical expectations. G3: Genes, Genomes, Genetics 10:89-107. https://doi.org/10.1534/g3. 119.400809

Sánchez-Bayo F, Wyckhuys KA (2019) Worldwide decline of the entomofauna: a review of its drivers. Biol Conserv 232:8-27. https://doi. org/10.1016/j.biocon.2019.01.020

Sauvant D, Giger-Reverdin S, Serment A, Broudiscou L (2011) Influences des régimes et de leur fermentation dans le rumen sur la production de méthane par les ruminants. INRA Productions Animales 24:433-446

Schader C, Muller A, Scialabba NE-H et al (2015) Impacts of feeding less food-competing feedstuffs to livestock on global food system sustainability. J R Soc Interface 12:20150891. https://doi.org/10.1098/ rsif.2015.0891

Schaffers AP, Raemakers IP, Sykora KV, Ter Braak CJF (2008) Arthropod assemblages are best predicted by plant species composition. Ecology 89:782-794. https://doi.org/10.1890/07-0361.1

Scherber C, Eisenhauer N, Weisser WW, Schmid B, Voigt W, Fischer M, Schulze ED, Roscher C, Weigelt A, Allan E, Bessler H, Bonkowski M, Buchmann N, Buscot F, Clement LW, Ebeling A, Engels C, Halle S, Kertscher I, Klein AM, Koller R, König S, Kowalski E, Kummer V, Kuu A, Lange M, Lauterbach D, Middelhoff C, Migunova VD, Milcu A, Müller R, Partsch S, Petermann JS, Renker C, Rottstock T, Sabais A, Scheu S, Schumacher J, Temperton VM, Tscharntke T (2010) Bottom-up effects of plant diversity on multitrophic interactions in a biodiversity experiment. Nature 468:553-556. https://doi.org/10.1038/nature09492

Scherber C, Mwangi PN, Temperton VM, Roscher C, Schumacher J, Schmid B, Weisser WW (2006) Effects of plant diversity on invertebrate herbivory in experimental grassland. Oecologia 147:489 500. https://doi.org/10.1007/s00442-005-0281-3

Schipanski ME, Barbercheck M, Douglas MR et al (2014) A framework for evaluating ecosystem services provided by cover crops in agroecosystems. Agric Syst 125:12-22. https://doi.org/10.1016/j. agsy.2013.11.004

Schuster, M.Z., Gastal, F., Doisy, D., et al. (2019) Weed regulation by crop and grassland competition: critical biomass level and persistence rate bioRxiv 572701. doi:https://doi.org/10.1101/572701

Sebillotte M (1990) Système de culture, un concept opératoire pour les agronomes. In: Les systèmes de culture. Inra, Versailles, pp 165-196

Sebilo M, Mayer B, Nicolardot B, Pinay G, Mariotti A (2013) Long-term fate of nitrate fertilizer in agricultural soils. Proc Natl Acad Sci U S A 110:18185-18189. https://doi.org/10.1073/pnas.1305372110

Silburn DM, Robinson JB, Freebairn DM (2007) Why restore marginal cropland to permanent pasture? Land resource and environmental issues. Trop Grasslands 41:139-153 http://tropicalgrasslands.info/ public/journals/4/Historic/Tropical\%20Grasslands\%20Journal\% 20archive/PDFs/Vol 41 2007/Vol 41032007 pp139 153.pdf. Accessed 16 March 2020

Skinner RH, Dell CJ (2016) Yield and soil carbon sequestration in grazed pastures sown with two or five forage species. Crop Sci 56:20352044. https://doi.org/10.2135/cropsci2015.11.0711

Smit HJ, Metzger MJ, Ewert F (2008) Spatial distribution of grassland productivity and land use in Europe. Agric Syst 98:208-219. https:// doi.org/10.1016/j.agsy.2008.07.004

Smith HG, Bruun M (2002) The effect of pasture on starling (Sturnus vulgaris) breeding success and population density in a heterogeneous agricultural landscape in southern Sweden. Agric Ecosyst Environ 92:107-114. https://doi.org/10.1016/S0167-8809(01) 00266-3

Steinbeiss S, Bessler H, Engels C et al (2008) Plant diversity positively affects short-term soil carbon storage in experimental grasslands. 
Glob Chang Biol 14:2937-2949. https://doi.org/10.1111/j.13652486.2008.01697.x

Stuhldreher G, Villar L, Fartmann T (2012) Inhabiting warm microhabitats and risk-spreading as strategies for survival of a phytophagous insect living in common pastures in the Pyrenees. Eur J Entomol 109:527-534. https://doi.org/10.14411/eje.2012.066

Sun D, Yang H, Guan DX, Yang M, Wu J, Yuan F, Jin C, Wang A, Zhang Y (2018) The effects of land use change on soil infiltration capacity in China: a meta-analysis. Sci Total Environ 626:1394-1401. https:// doi.org/10.1016/j.scitotenv.2018.01.104

Suter D, Rosenberg E, Frick R, Mosimann E (2008) Standard mixtures for the forage production. Agrarforschung 15(10):1-12

Thorsted MD, Olesen JE, Koefoed N (2002) Effects of white clover cultivars on biomass and yield in oat/clover intercrops. J Agric Sci 138:261-267. https://doi.org/10.1017/s0021859602002010

Tilman D, Cassman KG, Matson PA, Naylor R, Polasky S (2002) Agricultural sustainability and intensive production practices. Nature 418:671-677. https://doi.org/10.1038/nature01014

Tilman D, Clark M (2014) Global diets link environmental sustainability and human health. Nature 515:518-522. https://doi.org/10.1038/ nature 13959

Thomassen MA, van Calker KJ, Smits MCJ et al (2008) Life cycle assessment of conventional and organic milk production in the Netherlands. Agric Syst 96:95-107. https://doi.org/10.1016/j.agsy. 2007.06.001

Tomich TP, Brodt S, Ferris H et al (2011) Agroecology: a review from a global-change perspective. Annu Rev Environ Resour 36:193-222. https://doi.org/10.1146/annurev-environ-012110-121302

Tribouillois H, Constantin J, Justes E (2018) Cover crops mitigate direct greenhouse gases balance but reduce drainage under climate change scenarios in temperate climate with dry summers. Glob Chang Biol 24:2513-2529. https://doi.org/10.1111/gcb.14091

Tscharntke T, Klein AM, Kruess A et al (2005) Landscape perspectives on agricultural intensification and biodiversity-ecosystem service management. Ecol Lett 8:857-874. https://doi.org/10.1111/j.14610248.2005.00782.x

Turlin JP (2017) Le semis direct sous couvert permanent. Available at: http://www.bretagne.synagri.com/ca1/PJ.nsf/TECHPJPARCLEF/ $29857 / \$ F$ ile/Le\%20semis\%20direct\%20sous\%20 couvert\% 20 permanent $\% 20$ de $\% 20 \operatorname{tr} \%$ C $3 \%$ A 8 fle $\% 20$ blanc.pdf? OpenElement. Accessed 16 March 2020

Turner PA, Baker J, Griffis TJ, Venterea RT (2016) Impact of Kura clover living mulch on nitrous oxide emissions in a corn-soybean system. J Environ Qual 45:1782-1787. https://doi.org/10.2134/jeq2016.01. 0036

van der Burgt GJHM, van Eekeren N, Scholberg J, Koopmans C (2013) Lucerne (Medicago sativa) or grass-clover as cut-and-carry fertilizers in organic agriculture. Grassland Sci Eur 18:123-125

van Eekeren N, Bomméle L, Bloem J et al (2008) Soil biological quality after 36 years of ley-arable cropping, permanent grassland and permanent arable cropping. Appl Soil Ecol 40:432-446. https://doi.org/ 10.1016/j.apsoil.2008.06.010

Vernon RS, van Herk WG (2013) Physical exclusion of adult click beetles from wheat with an exclusion trench. J Pest Sci 86:77-83. https:// doi.org/10.1007/s10340-012-0472-8

Vertès F, Mary B (2007) Modelling the long term SOM dynamics in fodder rotations with a variable part of grassland. In: Proceedings of the Organic Matter Symposium, 17-19 July 2007, Poitiers, pp $549-550$

Vertès F, Mary B (2014) Part of grassland in ley-arable rotations is a proxy for predicting long term soil organic matter dynamics. In: Proceedings of the 18th Nitrogen Workshop, 30 June-3 July 2014, Lisboa, pp 347-348

Vertès F, Hatch D, Velthof G et al (2007) Short-term and cumulative effects of grassland cultivation on nitrogen and carbon cycling in ley-arable rotations. Grassland Sci Eur 12:227-246
Vertès F, Simon JC, Giovanni C et al (2008) Flux de nitrate dans les élevages bovins et qualité de l'eau: variabilité des phénomènes et diversité des conditions. C R Acad Agric France 94(3):6-26

Vertès F, Delaby L, Klumpp K, Bloor J (2018) C-N-P uncoupling in grazed grasslands and environmental implications of management intensification. In: Agroecosystem diversity: reconciling contemporary agriculture and environmental quality. Elsevier, Burlington, pp 15-34

Vrignon-Brenas S, Celette F, Piquet-Pissaloux A et al (2016) Early assessment of ecological services provided by forage legumes in relay intercropping. Eur J Agron 75:89-98. https://doi.org/10.1016/j.eja. 2016.01.011

Vrignon-Brenas S, Celette F, Piquet-Pissaloux A et al (2018) Intercropping strategies of white clover with organic wheat to improve the trade-off between wheat yield, protein content and the provision of ecological services by white clover. Field Crop Res 224:160-169. https://doi.org/10.1016/j.fcr.2018.05.009

Wade MR, Gurr GM, Wratten SD (2007) Ecological restoration of farmland: progress and prospects. Philos Trans R Soc B 363:831-847. https://doi.org/10.1098/rstb.2007.2186

Waldron BL, Peel MD, Larson SR, Mott IW, Creech JE (2017) Tall fescue forage mass in a grass-legume mixture: predicted efficiency of indirect selection. Euphytica 213(3):1-9. https://doi.org/10.1007/ s10681-017-1856-X

Weigelt A, Schumacher J, Roscher C, Schmid B (2008) Does biodiversity increase spatial stability in plant community biomass? Ecol Lett 11: 338-347. https://doi.org/10.1111/j.1461-0248.2007.01145.x

Weißhuhn P, Reckling M, Stachow U et al (2017) Supporting agricultural ecosystem services through the integration of perennial polycultures into crop rotations. Sustainability 9:2267. https://doi.org/10.3390/ su9122267

Westerman PR, Liebman M, Menalled FD et al (2005) Are many little hammers effective? Velvetleaf (Abutilon theophrasti) population dynamics in two-and four-year crop rotation systems. Weed Sci 53: 382-392. https://doi.org/10.1614/WS-04-130R

Westhoek H, Lesschen JP, Rood T et al (2014) Food choices, health and environment: effects of cutting Europe's meat and dairy intake. Glob Environ Chang 26:196-205. https://doi.org/10.1016/J. GLOENVCHA.2014.02.004

Whitehead DC, Bristow AW, Lockyer DR (1990) Organic matter and nitrogen in the unharvested fractions of grass swards in relation to the potential for nitrate leaching after ploughing. Plant Soil 123:39 49. https://doi.org/10.1007/BF00009924

Willoughby B, Addison P, Baker M (1997) Clover root weevil (Sitona lepidus) - a threat to the sustainability of white clover in New Zealand pastures? Proc NZ Grassl Assoc 59:23-28

Wu GL, Yang Z, Cui Z et al (2016) Mixed artificial grasslands with more roots improved mine soil infiltration capacity. J Hydrol 535:54-60. https://doi.org/10.1016/j.jhydrol.2016.01.059

Wu S, Wu P, Feng H, Merkley GP (2011) Effects of alfalfa coverage on runoff, erosion and hydraulic characteristics of overland flow on loess slope plots. Front Environ Sci Eng China 5:76-78. https:// doi.org/10.1007/s11783-011-0282-x

Zhang W, Ricketts TH, Kremen C et al (2007) Ecosystem services and dis-services to agriculture. Ecol Econ 64:253-260. https://doi.org/ 10.1016/j.ecolecon.2007.02.024

Zhao YG, Wu PT, Zhao SW, Feng H (2013) Variation of soil infiltrability across a 79-year chronosequence of naturally restored grassland on the Loess Plateau, China. J Hydrol 504:94-103. https://doi.org/10. 1016/j.jhydrol.2013.09.039

Zuazo VHD, Pleguezuelo CRR (2009) Soil-erosion and runoff prevention by plant covers. A review. Agron Sustain Dev 28:65-86. https:// doi.org/10.1051/agro:2007062

Publisher's note Springer Nature remains neutral with regard to jurisdictional claims in published maps and institutional affiliations. 